\title{
Article
}

\section{The UK Private Housebuilding Sector: Social Media Perspectives}

Craig, Nigel, Pilcher, Nick, MacKenzie, Rebecca and James, Boothman

Available at http://clok.uclan.ac.uk/34021/

Craig, Nigel, Pilcher, Nick, MacKenzie, Rebecca and James, Boothman ORCID: 0000-0001-7286-6442 (2020) The UK Private Housebuilding Sector: Social Media Perspectives. International Journal of Housing Markets and Analysis . ISSN 1753-8270

It is advisable to refer to the publisher's version if you intend to cite from the work. http://dx.doi.org/10.1108/IJHMA-05-2020-0051

For more information about UCLan's research in this area go to http://www.uclan.ac.uk/researchgroups/ and search for <name of research Group>.

For information about Research generally at UCLan please go to http://www.uclan.ac.uk/research/

All outputs in CLoK are protected by Intellectual Property Rights law, including Copyright law. Copyright, IPR and Moral Rights for the works on this site are retained by the individual authors and/or other copyright owners. Terms and conditions for use of this material are defined in the policies page.

\section{CLoK}

Central Lancashire online Knowledge www.clok.uclan.ac.uk

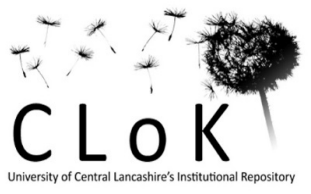




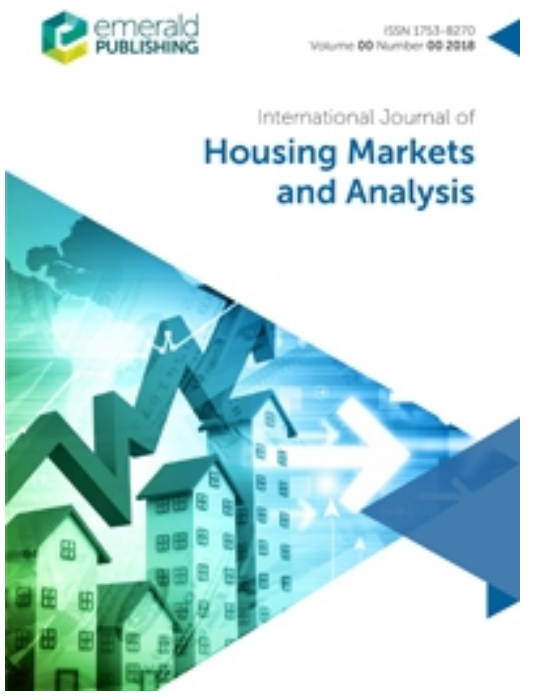

\section{The UK Private Housebuilding Sector: Social Media Perspectives}

\begin{tabular}{|r|l|}
\hline Journal: & International Journal of Housing Markets and Analysis \\
\hline Manuscript ID & IJHMA-05-2020-0051.R1 \\
\hline Manuscript Type: & Research Paper \\
\hline Keywords: & $\begin{array}{l}\text { Private housebulding sector, Quality, Social media, Ombudsman, } \\
\text { Customer satisfaction, Defects }\end{array}$ \\
\hline \multicolumn{2}{|l}{} \\
\hline
\end{tabular}

\section{SCHOLARONE ${ }^{m}$ \\ Manuscripts}




\section{The UK private housebuilding sector: Social media perspectives}

\section{Introduction}

3 In 2019 the UK construction sector was valued at over $£ 41 \mathrm{Bn}$; constituting $25 \%$ of the total UK 4 construction industry, with $21 \%$ of this amount being private housebuilding. This created 196,089 new 5 housing units across the UK in 2018 (Rhodes, 2019), although this figure remains below UK 6 Government targets. Most companies make healthy profits, and annual accounts of the top ten 7 housebuilders from $2005 / 06$ to $2017 / 2018$ show profit margins ranging from $13.29 \%$ to $24 \%$ in 8 2005/06 and all but one housebuilder making yearly profits from 2013 - 2018_e.g. Branson, 2013, 9 Gardiner, 2019). Arguably, housing contractors should be keen to improve their reputations 10 (Wilkinson, 2014) and build quality. Indeed, private sector competitiveness has been the underpinning 11 ethos of UK government policy for the last 40 years (ef.cf. Hayek, 1980) and claimed by many 12 Government reports (e.g. Latham, 1994; Egan, 1998; Barker, 2004) to increase quality and value.

Yet, despite some Housebuilding Federation (HBF) surveys and results since 2000 showing improvements, much criticism of the sector exists (Baldry, 1997), and customer perceptions of end product quality are low, as illustrated by the recent 2016 All-Party Parliamentary Group (APPG) report. Buyers of private houses have been left in tears (Sommerville \& McCosh, 2006), experiencing severe stress from numerous faults (Craig, 2007) in what is commonly their largest lifetime purchase (Lorentzen, 1996). Market and Opinion Research International Ltd (MORI) and Home Builders Federation (HBF) annual surveys since 2000 show overall dissatisfaction with new-build homes and many defects reported. This situation is exacerbated by the absence of protective legislation, with newly built homes being exempt from the Sales of Goods Act of 1979 act(Sales of Goods Act, 1979 (HMSO, 1994)). Further, many instruments ostensibly intended to assure quality, such as the Five-Star builders rating scheme, are used strategically by the housebuilding sector as marketing tools and are heavily biased (Boothman et al., $n$, , Craig \& Somerville, 2018). These fail to give the same certification and guarantee of quality that exists through regulatory structures such as those elsewhere in the world (e.g. Singapore (Pheng and Premnath, 2019)). Overall therefore, despite receiving media attention in programmes such as ITV Tonight's 'New Build Nightmares?' (ITV, 2017), individual customers have struggled to publically express views.

However, the explosion in social media offers customers new outlets, and Facebook can reach wider and larger audiences than traditional media (Chu \& Kim, 2011). Facebook forums allow instant display of comments, and users can connect with others to share experiences, and gain advice (Reid \& Duffy, 2018). This paper first reviews key literature around quality and customer perceptions of the UK private housebuilding sector. It then presents and thematically analyses (Braun \& Clarke, 2006) 147 comment posts gathered from nine Facebook forums under themes of: safety; standards; quality; workmanship; customer service; finance and money; advice; NHBC; ombudsman and; page closures. Results corroborate the picture of poor quality in UK private housebuilding. Significantly, the novel use of social media forum comments provides a raw and often visceral picture of frustration, anger, and feelings of neglect. It is recommended such data be harnessed by official bodies and by the 'new home ombudsman' the UK Government aims to establish in 2020 (Barker, 2020) to help address the performance issues experienced. 
Despite its significancet benefits to the economy ${ }^{1}$, the UK construction industry has continually battled with negative public perceptions, and has for decades faced issues of high cost, low quality and of poor health and safety (Emmerson, 1962; Ball, 1988; Boothman et al., 2018), with Turin's (1969) noting that "construction has an image synonymous with high cost, low quality, chaotic working practices and a poor health and safety record" still resonant today (e.g. Ramezany, 2017). The Industry's low self-esteem and generally poor client relations (Farmer, 2016, p.g 40) reinforce this. Negative public perceptions of the industry stem from building failures, quality issues, workforce accidents and fatalities, increases in cost and time, low professionalism, low productivity, and environmentally hazardous and disruptive practices (Bodapati \& Naney, 2001). The industry appears resistant to change, with some noting it lacks innovative thinking (Reichstein et al., 2005), and others its failure to integrate technology effectively (Ramezany, 2017). The stereotype of the 'cowboy' builder, i.e. someone who is "incompetent, dishonest and a tax evader" (Proverbs et al., 2000, p. 74) remains widespread, perennially haunting the industryfy for many years (Furin, 1969; Haupt \& Harinarain, 2016). Construction industry reports (notably Latham 1994; and Egan, 1998) do highlight the need to modernise to improve quality, efficiency, and thus the industry's reputation. However, such reports only commonly identify issues and fail to provide any overall strategy for change. As Proverbs et al. (2000) note, the aim of enhancing the reputation of the industry by improving quality and efficiency is common, but has not translated into practice.

QEElements such as quality isare key to improving the industry and, critically, play a fundamental role in customer expectations. Given the sizeable investment in a new-build home by a customer, it is understandable high levels of quality are expected (Parasuraman et al., 1985). Quality is measured by the gap between customers' expectation levels prior to receiving the product, and the actual expectation customers' have on receiving it (Sommerville et al., 2012). Since Aristotle, quality has been considered as "indicating the goodness of an object" (Shewarth, 1931, p.37). With buying a new build home, customer expectations are set by the contractor by-showcasing the prospective property via the use of a 'show home', because ultimately the home builder is the client and it is they therefore that set the specification of the new home, not the home buyer (Craig, 2007, p.g 2). Yet, 'show homes' are often furnished with premium high quality fittings and furnishings, and any failure to meet this high quality in the purchased final product can result in customer dissatisfaction (Georgiou et al., 1999). Contractors, perhaps understandably, present standards within show homes that are unlikely to be met, a situation encapsulated by Farmer (2016, p.g 16) as being that "what is promised regardless of the challenge, is often not delivered".

Continuous monitoring by the UK government, the NHBC, and the HBF reveal starkly negative customer satisfaction. For example, a recent NHBC report found $99 \%$ of new build property owners reported snags or defects, and $34 \%$ found more problems than originally expected (NHBC, 2019). Of concern is both the sheer volume of these defects, and, importantly, their range and severity, "from leaky ceilings to holes in the ground" (Clements \& Lewis, 2019, para. 1npg). Notably, although previous research has suggested "the house price will generally reflect the quality an overall service received" (Craig, 2007, p.g 47), it is increasingly apparent that even a premium price does not guarantee quality. Although anecdotal, this is evidenced by some new homeowners finding 700 defects in a new Persimmon $£ 280,000$ house (Forsyth \& Sandhu, 2019). Similarly, by Clark's (2005) reports of faults with Charles Church homes, and by a customer's experience of finding fifty faults, some serious, in a £310,000 Barrett Home (Forsyth \& Sandhu, 2019, npg. ef.cf. Barrie, 2007).

In the mainstream media, such poor quality and attention to detail is frequently reported (e.g. Curtis, 2011). Murray (2005, p.g 10) is quoted as saying "House builders just don't care" and more

\footnotetext{
${ }^{1}$ As noted above, housing has recently been found to be worth $f 41$ billion in revenue; as a whole the construction sector created $£ 117$ billion in revenue in 2018 (Rhodes, 2019)
} 
recent news, notes "the builder Persimmon lacks minimum house standards" (BBC, 2019, para. 1npg), with many new build homes lacking or incorrectly installing fire-stopping cavity barriers or having them installed incorrectly-(BBC 2019). The extent and scale of defects is extreme, one owner, having her new Linden home deemed inhabitable by the NHBC, was still paying monthly bills and her mortgage (Deeks, 2019). A key issue is the many stages defects can be established and then impact later without any possibility of correction. For example, defects resulting by the site team will equate to increasing numbers and severity of defects at the handover stage (Wilkinson, 2014).

Regarding compensation and customer rights, although the Sales of Goods Act (1979 (HMSO, 1994)) does not protect house-buyers, certain guarantees are claimed to exist. The NHBC provides a 10 year warranty called Buildmark, and the Five-Star Builders scheme claims to give customers reliable housebuilder ratings before purchase (Boothman, et al., Craig \& Somerville, 2018zz). Under the Buildmark scheme, housing contractors provide warranties for the first two years, agreeing to rectify any defects not resulting from wear and tear or lack of maintenance, with the NHBC providing homeowners with an independent resolution service and guarantee (NHBC, 2020). Once this two-year period ends, the NHBC provides eight further years of protection for homeowners if contractors fail to meet NHBC requirements, but this is commonly from a technical viewpoint only. The homebuyer is exposed to many functional aspects (how the house looks and feels) although these functional items tend to be ignored (Craig, 2007, p.g 46). Yet, the success of the Buildmark scheme is debatable. Some customers have complained, although relatively few published cases exist. Yet, this lack of published cases is often because the NHBC enforces homeowners to sign non-disclosure agreements, preventing them from-talking to the media and even-their neighbours about any issues-experienced (Ruddick, 2017). This both suggests the NHBC recognises the negative impact such perspectives could have, and also that dissatisfied homeowners have little ability to relate their experiences. Further, the Five Star Builders scheme intended to give customers a rating of their housebuilder before-they buying, is strategically implemented by the industry inas a marketing-tool. By drawing on results gathered at particular stages in the house buying process, customers receive a biased, and overly favourable impression, of the housebuilder (Boothman, Craig \& Somerville, et al., 2018)

The ultimate impact of all the above on the industry is a negative one. This subsequently impacts on industry perceptions by those considering employment, who often conclude it is not a "desirable career path" (Sargent, 2020, introductionnpg). There is a consequent significant skill shortage, and low productivity which contributes towards poor workmanship (Farmer, 2016, p.g 16). This is despite government demand for homes targeting 300,000 new build homes a year by the mid2020s (Sargent, 2020). Such initiatives as the Considerate Constructors Scheme (CCS), founded in 1997, have arguably had limited impact given the continually emerging negative reports (e.g. Boothman et al., Ramezany, 20187). The industry therefore would appear impervious-set to be able to changeentinue regardless, continuingand to build new homes often dangerously low in quality about which the public have little opportunity to commentspread widespread word of mouth about. That is, until the advent of social media.

Recent years have seen an explosion in social media platforms such as Facebook, Instagram and Twitter, with monthly active Facebook Users recently topping 2.5 billion worldwide (Statista, 2020). Social media channels of communication are the focus of much research in the area of marketing (e.g. Arora et al., 2019), with published literature ranging from areas such as attempting to engage fans of football clubs (Vale \& Fernandes, 2018) to strategic marketing of the Sicilian wine industry (Galati et al., 2017). Social media is considered to have a wider reach and greater impact than traditional media (Chu \& Kim, 2011), something which will increase over time, particularly with decreasing sales of traditional media such as newspapers (Greenslade, 2009). In the context of housebuilding, some have noted social media's potential to propel the discontent of new homeowners straight into the public domain, highlighting that private housebuilders must take quality seriously 
(Gardiner, 2017). Yet, to date, social media comments remain little researched in relation to the construction sector, despite the fact that housing is a key example of a product with high consumer involvement.

\section{Data: sources and approaches to collection and analysis.}

7 recent years have seen an explosion in social media platorms such as acebook, Instagram and

8 I witter, with monthly active Facebol Users recently topping 2.5-billion worldwide (Statista, 2020).

9 Social media channels of communication areconsided to have a wider ach and ofeaterimpact 10 than traditional media (Chu \& Kim, 2011), something which will increase over time, particularly with decresing sales of traditional media such as newspers (Greenstade, 2009). In the context of

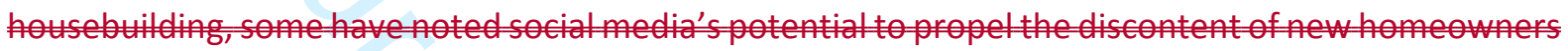
straight into the public domain, highlighting that private housebuilders must take quality seriously (Gardiner, 2017). Yet, to date, socialmedia comments remain litteresearched.

In this paper we present and discuss a combined content analysis (Morgan 1993) and thematic analysis (Braun \& Clarke, 2006) of comments ( $N=147)$ from Facebook forums that focused on the key themes related to quality in new build homes that were the concerns of owners. This combination allowed for the focus on key occurring issues in the content (Morgan, 1993) by focusing on their repeated mentions in responses by owners, yet gave the flexibility to identify emerging issues as well as those anticipated from the literature (Braun \& Clarke, 2006). Facebook Forums are- a form of online community that allow users to gain answers, advice and support, and connect with others, and comments posted are of an immediate and highly revealing nature (Reid \& Duffy, 2018). In essence, the comments are arguably similar to ones which would be shared in any face-to-face interaction, as research into social media shows that overall, an "overarching observation is that the two contexts are essentially similar" (Sheldon, 2015, p.15). Indeed, aspects such as the ability to influence others' opinions have been found to be broadly similar between traditional and social media (Weeks et al., 2017). Admittedly, much research into social media shows the presence of 'herd' mentality whereby individuals follow what others do (e.g. Vishwanath, 2015), thereby suggesting behaviour (and therefore what is said) online may differ greatly from behaviour and comments offline. However, such research tends to focus on how 'phishing' attackers can succeed by creating false popularity (Vishwanth, 2015), or how any herd mentality will operate by individuals' following friends recommendations on personal sites (Wu et al., 2016). In addition, there are subtle differences such as different expectancy norms online whereby more information is shared by an individual if they see others sharing frequently, and concern over privacy is greater even if private data is still shared (Sheldon, 2015). However, broadly speaking, offline and online communication is similar, and this is particularly so with non-personal sites such as Forums. Nevertheless, and as we argue here, the way in which the comments are communicated on such Forums is highly immediate and attempts to emulate and replicate conversational discussions. To do this, the visual impact of the comments is key, so rather than being presented as formally written and objective messages in text alone, they are interspersed with exclamation marks, emojis, and the use of capitals, in communication that more closely emulates the impact, intonation or stress of verbally delivered messages than written text alone (cf. Voloshinov, 1929).

Our data is drawn from 147 comments gathered from nine different forums set up by unsatisfied new home buyers and now used by thousands. This number was deemed sufficient to reach saturation (Fusch \& Ness, 2015) as any further comments repeated similar themes. The nine forums were selected as they had the highest number of members and therefore the most activity 
these forums and post freely, and the comments box displayed below each post allows others to question and discuss the original post. The providing a check on the information published, and increasing the reliability of the comments. Regarding thics, as facebook is public, comments are post voluntarily and available for all tosee.

The comments were published in 2019 and 2020, and total just under 10,000 words. A 'comment' is a person giving their view on a situation, either an initial comment, or a response to another comment; it might focus on one issue (e.g. resealing windows) or on many (e.g. about the colour of mortar, but also NHBC). Comments ranged from 20 to 350 words or more. As noted immediately above, $t$ The effect of the comments is heightened by their informal linguistic nature, use of exclamation marks, photos, colloquial language, grammatical inaccuracies, and upper case capital letters and emojis for emphasis ${ }^{2}$. Such usage has a huge impact, and is particularly notable given the lack of anonymity. For example the comment "please share the hell out of this so others no [sic: know] to check everything" comes across with far greater impact in the original "PLEASE SHARE the hell out of this so others no [sic: know] to check EVERYTHING!!".

Analysis of the content was thematic, using a combined 'top-down' deductive and 'bottomup' inductive approach (Braun \& Clarke, 2006) to identify key themes. This was because it was assumed certain 'top-down' themes would be identifiable (e.g. 'safety' and 'workmanship') but considered unexpected themes might emerge 'bottom-up'. This was indeed the case, and provided a structure but allowed for a flexibility to accommodate unanticipated aspects. The pages are under constant scrutiny by other homeowners, providing a check on the information published, and increasing the reliability of the comments. A conscious strategy was adopted to select comments that had many other users posting responses of similar experiences. Whilst it is possible to interpret this as a herd mentality approach that illustrates a decoupling of perception and reality (cf. Vishwanath, 2015), we argue rather that this increases validity and reality, particularly as many comments reflected the experiences reported in the media, and were based not on personal preferences so much as events occurring in the homes. It was often the case that accompanying photographic images were posted for support. s. Regarding ethics, as Facebook is public, comments are posted voluntarily and available for all to see.

\section{Results and Analysis}

The results and qualitative analysis are categorised and presented below under ten themes of: safety; standards; quality; workmanship; customer service; finance and money; advice; NHBC; ombudsman and; page closures. Figure 1. details the number of comments in these themes:

\footnotetext{
${ }^{2}$ We note that the emojis we use in this paper are not identical to those used in the social media posts in all cases (e.g. the shade of colour sometimes differs), but where they differ we have selected emojis as similar as possible, and have always selected those with an identical function.
} 


\section{Comment Categories}

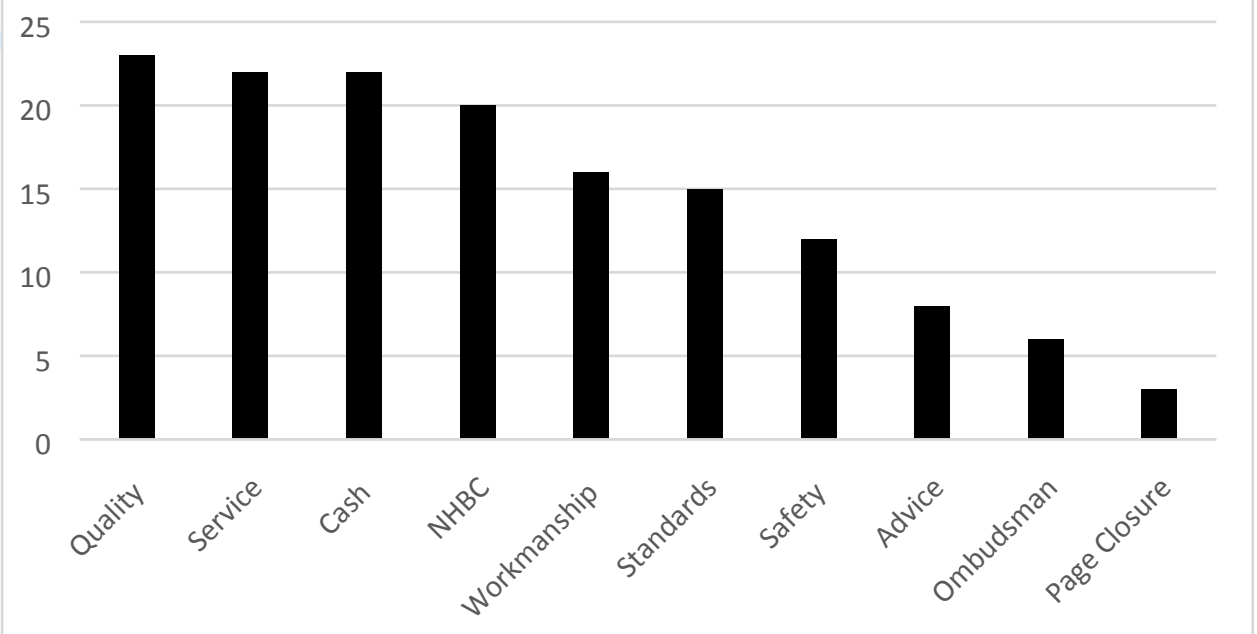

1

2 Figure 1: Numbers of comments obtained within each theme.

Below, we focus on each category in turn, first providing a selection of illustrative comments and subthemes in a table, then analysing these against the literature and other sources such as traditional media or legislation. Where comments related to more than one theme, the salient theme is focused on. As the comments are in the public domain, many housebuilders are named in the data selected below (Persimmon, Taylor Wimpey (TW), Croudace, and Linden). We note others were mentioned in the comments but are not in the selected data presented below (Bovis or Barratt).

9 Table 1. Safety (issues highlighted)

\begin{tabular}{|l|l|l|l|}
\hline Themes & Comments \\
\hline $\begin{array}{l}\text { Poor } \\
\text { fixings }\end{array}$ & $\begin{array}{l}\text { Unsafe kitchens nearly killed my } \\
\text { pregnant wife... (Due to light weight } \\
\text { fixings) }\end{array}$ & $\begin{array}{l}\text { Typical Taylor Wimpey I } \\
\text { had tiles fall off the } \\
\text { room they don't seem } \\
\text { this serious until one hits } \\
\text { one of my kids }\end{array}$ & $\begin{array}{l}\text { The hand basin in my } \\
\text { downstairs toilet was } \\
\text { flexing on the wall... The } \\
\text { plasterboard was the only } \\
\text { thing holding the hand } \\
\text { basin up! No wonder it was } \\
\text { flexing. }\end{array}$ \\
\hline $\begin{array}{l}\text { Structural } \\
\text { security }\end{array}$ & $\begin{array}{l}\text { They opened a bedroom window } \\
\text { and it just fell out on to the patio! } \\
\text { Great house }\end{array}$ & $\begin{array}{l}\text { Sadly this is our home } \\
\text { that collapsed in the } \\
\text { middle of the night }\end{array}$ & $\begin{array}{l}\text { My Garage was marked } \\
\text { unsafe a couple of weeks } \\
\text { ago, amongst other } \\
\text { regulation breaches. }\end{array}$ \\
\hline $\begin{array}{l}\text { Safety of } \\
\text { the estate }\end{array}$ & $\begin{array}{l}\text { My 4 year old Son has tripped over } \\
\text { and split his head open on a } \\
\text { Persimmon... development site...I'm } \\
\text { fuming }\end{array}$ & $\begin{array}{l}\text { We had a break in last night...Be warned the locks } \\
\text { on patios are not anti snap... These burglars know } \\
\text { our locks are crap- change them now before your } \\
\text { the next victim. }\end{array}$ \\
\hline
\end{tabular}

Safety was key, and related to poor fixings, structural security or the safety of the estate. One property owner's child tripped and severely hurt his head, as a road was incomplete. Here, despite it being the contractor's duty to protect the health and safety of employees and the public (Health and Safety at Work Act, 1974 (HSE Gov, 2020)), this comment suggests public safety is considered compromised. Furthermore, regarding structural security, one customer's home collapsed entirely. This owner posted photographs of the collapse on the forum, commenting further that the contractor is "acting swiftly to correct all damage, which is positive, but sadly it takes something as horrendous \& 
on the BBC News (BBC 2019) and the same structural issues were highlighted on similarly designed houses on the estate. Also, poor fixings in kitchens and bathrooms (ef.cf. Barrie, 2007) were considered instrumental in causing near accidents of a potentially serious nature, one customer reporting how he felt his pregnant wife had nearly been killed, and another that falling tiles could at times hit children.

\section{Table 2. Standards (technical items)}

\begin{tabular}{|l|l|l|l|}
\hline Themes & Comments \\
\hline $\begin{array}{l}\text { Fire } \\
\text { Barriers }\end{array}$ & $\begin{array}{l}\text { No fire barriers, parts of houses } \\
\text { "falling off" why the hell are people } \\
\text { still buying them? }\end{array}$ & $\begin{array}{l}\text { Persimmon inspection } \\
\text { told me my cavity } \\
\text { barriers were ok } \\
\text { but...independent } \\
\text { inspector... identified I } \\
\text { have no barriers around } \\
\text { my electrical boxes. }\end{array}$ & $\begin{array}{l}\text { I've just had a call to say } \\
\text { my inspection from 11 } \\
\text { days ago (!!!!!) has } \\
\text { found that there are } \\
\text { 'some' missing fire } \\
\text { barriers. }\end{array}$ \\
\hline Plumbing & $\begin{array}{l}\text { The heating engineers...told me on their first visit } \\
\text { that the tank and how it had been installed was } \\
\text { well below standard. I rang and spoke to } \\
\text { persimmon customer services who were even } \\
\text { more shocking than the building work }\end{array}$ & $\begin{array}{l}\text { After having a leak from water tank } \\
\text { into downstairs toilet we discovered } \\
\text { blow off pipe from water tank was } \\
\text { never connected. They confirmed } \\
\text { it...didn't meet regulations...We also } \\
\text { discovered our water tank was never } \\
\text { commissioned }\end{array}$ \\
\hline $\begin{array}{l}\text { Structural } \\
\text { security }\end{array}$ & $\begin{array}{l}\text { Our TW home has been built (like many others on } \\
\text { our estate) without gable end straps }\end{array}$ & $\begin{array}{l}\text { Our block of flats are 4yrs old and } \\
\text { have been told we have subsidence. }\end{array}$ \\
\hline $\begin{array}{l}\text { Finishing } \\
\text { Quality }\end{array}$ & $\begin{array}{l}\text { (they) tell me this decorating and finish complies with their standards! Definitely not my } \\
\text { standards for a "luxury" house. }\end{array}$ \\
\hline
\end{tabular}

8 Customers were aware of issues relating to standards themselves (e.g. in relation to fire barriers) and 9 learned of issues from inspection reports (e.g. in relation to plumbing). Thus, in these forums there 10 was a synergy between customer knowledge, and knowledge from inspections, producing heightened awareness of issues, and subsequent communication of these issues through social media. Although building regulations and meeting minimum standards are legal requirements buildings must adhere to (Local Government Association, 2017), it still remains possible, for whatever reasons, that for these buyers certain building standards were not being met. These could be serious safety concerns regarding fire barriers and structural security, or potentially damaging issues related to plumbing, or mismatches in perceptions of 'standards' between builders and buyers (ef.cf. Somerville et al. 2012).

Table 3. Quality issues in general

\begin{tabular}{|l|l|l|l|}
\hline Themes & \multicolumn{3}{|l|}{ Comments } \\
\hline Legislation & $\begin{array}{l}\text { Another few shots of Taylor Wimpey's } \\
\text { attempt of house building...if you think } \\
\text { these are rare cases and it will never } \\
\text { happen to you, well I was one of them } \\
\text { idiots who ignored the advice of current } \\
\text { TW homeowners!!!! You have been } \\
\text { warned X }\end{array}$ & $\begin{array}{l}\text { I had to move out of my } \\
\text { Linden Home for the } \\
\text { SECOND time on 19/01/16 } \\
\text { and I've NEVER been able } \\
\text { to move back. (they) } \\
\text { changed the locks, ran off } \\
\text { with my keys and refused } \\
\text { to fix it }\end{array}$ & $\begin{array}{l}\text { The whole industry is so } \\
\text { badly run and new housing } \\
\text { legislation is so flawed you } \\
\text { all need to raise this with } \\
\text { your MP. }\end{array}$ \\
\hline Mould & $\begin{array}{l}\text { told the mold growing inside the kitchen } \\
\text { units and on the stairs... was because we } \\
\text { never put the heating on immediately to } \\
18^{\circ}\end{array}$ & $\begin{array}{l}\text { mould above the front } \\
\text { door, underneath the } \\
\text { bathroom... }\end{array}$ & $\begin{array}{l}\text { issues round our windows! } \\
\text { Constantly growing } \\
\text { mould!! I'm wiping it away } \\
\text { every 2 days!! }\end{array}$ \\
\hline
\end{tabular}




\begin{tabular}{|l|l|l|l|}
\hline $\begin{array}{l}\text { Cracking / } \\
\text { Brickwork }\end{array}$ & $\begin{array}{l}\text { Has anybody had worse pointing than } \\
\text { this on their new build? I don't even } \\
\text { know what to say? I'm astounded that } \\
\text { it's passed any sort of inspection } \\
\text { Major crack in the flooring } \\
\text { from one end of the house }\end{array}$ & $\begin{array}{l}\text { this has to be the worst!! } \\
\text { were creaking along the } \\
\text { whole of the upstairs in } \\
\text { every room. Causing cracks } \\
\text { along the joins where } \\
\text { ceiling meets wall and } \\
\text { floor/ skirting boards... } \\
\text { They're all over you like a } \\
\text { rash when you're in the } \\
\text { process of buying, but the } \\
\text { second you move in that's } \\
\text { it. }\end{array}$ \\
\hline Garden & $\begin{array}{l}\text { Apparently 10 inches of turf up the back of your } \\
\text { fence is acceptable because the fence is } \\
\text { "treated". }\end{array}$ & $\begin{array}{l}\text { The garden floods constantly and floods the } \\
\text { garage ruining anything in there. The drain is six } \\
\text { inches above ground level, }\end{array}$ \\
\hline $\begin{array}{l}\text { Sound } \\
\text { proofing }\end{array}$ & $\begin{array}{l}\text { I am kept awake by the neighbours boiler which is } \\
\text { on the party wall, switched on all night }\end{array}$ & $\begin{array}{l}\text { We can hear neighbours voices clearly, light } \\
\text { switches and sockets being turned on and off, } \\
\text { blinds being opened }\end{array}$ \\
\hline
\end{tabular}

1

2

3

Quality was a key concern, and here, the 'bold red cross' emoji used by the customer regarding their overall experience of their house (legislation) and the 'person holding their hands up in despair' emoji at the crack in their flooring emphasise the feelings of anger and frustration. Also, the use of capitals (e.g. in relation to having to move out) and of exclamation marks (e.g in relation to the mould growing around the windows) further emphasise the degree of anger and frustration felt. Clearly, the comments suggest the aspiration for zero defects at handover (Egan, 1998) is not being met. Generally, comments focus on poor materials (windows), or poor workmanship (turf; pointing). Notably, a pattern emerges of either a mismatch between customer and housebuilder expectations of quality (Somerville et al., 2012), or of standards and minimum requirements not being met, and of the fault residing with the customer, not the housebuilder. One customer was "astounded that it's passed any sort of inspection" and another told that the mould was because they had not put "the heating on immediately to $18^{\circ \prime}$. Poor soundproofing also suggests minimum standards not being met. Here, an abdication of responsibility is clearly felt, the housebuilder described as "all over you like a rash when you're buying, but the second you move in that's it."

Table 4. Workmanship

\begin{tabular}{|c|c|c|c|}
\hline Themes & Comments & 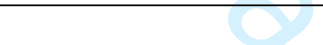 & \\
\hline Unsatisfied & $\begin{array}{l}\text { I am disgusted with the shoddy } \\
\text { workmanship on a lot of the house, its } \\
\text { truly shocking }\end{array}$ & $\begin{array}{l}\text { We bought a } \\
\text { "luxury" home, } \\
\text { definitely not. } \\
\text { Shoddy } \\
\text { workmanship and a } \\
\text { nightmare to get } \\
\text { snagging done. }\end{array}$ & $\begin{array}{l}\text { The whole industry } \\
\text { needs a massive shake } \\
\text { up }\end{array}$ \\
\hline Reworks & $\begin{array}{l}\text { Their excuse? The homes are all built by } \\
\text { hand so won't be perfect }\end{array}$ & \multicolumn{2}{|c|}{$\begin{array}{l}\text { we've had } 5 \text { rooms re-plastered so far, how they } \\
\text { can claim to be a quality builder is beyond me. }\end{array}$} \\
\hline $\begin{array}{l}\text { Endless } \\
\text { Snags }\end{array}$ & $\begin{array}{l}\text { Our house has a huge number of } \\
\text { snags...they should have sold us a } \\
\text { completed house! }\end{array}$ & $\begin{array}{l}\text { We moved into a TW } \\
\text { property recently... } \\
\text { and pretty much } \\
\text { every window has } \\
\text { scratches inside the } \\
\text { glass. }\end{array}$ & $\begin{array}{l}\text { Utility room tap and } \\
\text { pipes... plumbed in } \\
\text { wrong... Downstairs loo } \\
\text { sink... hanging off the } \\
\text { wall and under sink } \\
\text { fittings looked like } \\
\text { they'd been flung on the }\end{array}$ \\
\hline
\end{tabular}




\begin{tabular}{|l|l|l|l|}
\hline & & & $\begin{array}{l}\text { wall. Boiler was } \\
\text { connected wrong and } \\
\text { upstairs thermostat was } \\
\text { heating downstairs and } \\
\text { vice versa. }\end{array}$ \\
\hline
\end{tabular}

2 Comments related to workmanship suggest poor attention to detail and haste created endless snags, 3 a need for reworks (ef.cf. Curry, 2019), and highly unsatisfied customers. Here again, the use of the 4 three 'red angry face' emojis highlights anger at a perceived abdication of responsibility, that as "the 5 homes are all built by hand they won't be perfect." Further, there is a prevalence of minor faults, 6 perhaps due to haste, such as scratches in windows and incorrect plumbing. Here again, the mismatch 7 again between customer expectations and housebuilder products is clear, for example regarding what 8 constituted a 'luxury' home. Notably, an emerging theme, which also arises below, is that the 'whole 9 industry needs a massive shake-up.' In other words, that the causes of such issues are at a 10 fundamental and systemic level.

Table 5. Customer Service

\begin{tabular}{|c|c|c|c|}
\hline Themes & Comments & & \\
\hline $\begin{array}{l}\text { Service } \\
\text { attitude }\end{array}$ & $\begin{array}{l}\text { Kept our dignity despite awful, rude and } \\
\text { arrogant responses...site manager when } \\
\text { we moved in said "who signed this off?" } \\
\text { He didn't know what to say when we } \\
\text { said "you did!" }\end{array}$ & $\begin{array}{l}\text { The receptionist... is } \\
\text { extremely rude; we ask her } \\
\text { what's her name and she } \\
\text { says you don't need to } \\
\text { know that, God Almighty!!! }\end{array}$ & $\begin{array}{l}\text { We are having the same } \\
\text { encounters with customer } \\
\text { service. The area manager } \\
\text { is also extremely insulting. } \\
\text { We're still fighting } 9 \text { years } \\
\text { on!!! }\end{array}$ \\
\hline $\begin{array}{l}\text { Lack of } \\
\text { Customer } \\
\text { Service }\end{array}$ & $\begin{array}{l}\text { The customer service is appalling, how } \\
\text { they think they can speak to customers } \\
\text { and treat people this way is shocking. }\end{array}$ & $\begin{array}{l}\text { Customer service is } \\
\text { appalling... reported it to } \\
\text { Persimmon.... Phoned back } \\
\text { twice on Thursday as } \\
\text { nobody came. Eventually } \\
\text { spoke with the M.D. ... who } \\
\text { said a roofer would be here } \\
\text { first thing Friday. We have } \\
\text { tried contacting ... all day } \\
\text { as still nobody has been } \\
\text { but all calls gone to } \\
\text { answerphone }\end{array}$ & $\begin{array}{l}\text { We are not they're } \\
\text { customers, we are they're } \\
\text { victims! }\end{array}$ \\
\hline $\begin{array}{l}\text { Lack of } \\
\text { Response }\end{array}$ & $\begin{array}{l}\text { We've had nothing but problems with } \\
\text { the sales team, They never respond and } \\
\text { have barely guided us through any of } \\
\text { this process. }\end{array}$ & $\begin{array}{l}\text { I been fighting to get work } \\
\text { done for over a year....no } \\
\text { one cares...customer } \\
\text { service is a title only }\end{array}$ & $\begin{array}{l}\text { They don't care and the } \\
\text { site Forman and site } \\
\text { manager are a joke at the } \\
\text { persimmon development }\end{array}$ \\
\hline $\begin{array}{l}\text { What is } \\
\text { acceptable? }\end{array}$ & $\begin{array}{l}\text { Your fence is acceptable because the } \\
\text { fence is "treated". The words of the } \\
\text { assistant site manager. No mate, it's not } \\
\text { acceptable }\end{array}$ & $\begin{array}{l}\text { I am not accepting being } \\
\text { treated like a fool } \\
\text { anymore. }\end{array}$ & $\begin{array}{l}\text { After meeting with the big } \\
\text { cheeses from Persimmon.. } \\
\text { on Monday and hoping for } \\
\text { resolve... THE TERM ITS } \\
\text { WITHIN TOLERANCE was } \\
\text { used like verbal } \\
\text { Diarrhoea... }\end{array}$ \\
\hline
\end{tabular}


1 Reflecting the comments presented in above sections, customers were unhappy with the nature and level of service. This could be service attitude of staff, or a lack of customer service or response, again underlining mismatches between customer expectations and housebuilder standards (ef.cf. 4 Somerville et al., 2012). The language is often highly informal and reveals intense anger, for example 5 'God Almighty!!!' with three exclamation marks. Also, the idea of customers being 'victims' and that 6 'they don't care' suggests a complete lack of any duty of care to customers (ef.cf. Murray 2005). This 7 is further illustrated by the housebuilder understanding of 'acceptable' relating to a fence being 8 'treated' clashing with the customer understanding, and the use of capitals for 'THE TERM ITS WITHIN 9 TOLERANCE' showing frustration at this gap.

Table 6. Finance and Money

\begin{tabular}{|c|c|c|c|c|}
\hline Themes & \multicolumn{4}{|l|}{ Comments } \\
\hline Compensation & \multicolumn{2}{|c|}{$\begin{array}{l}\text { My electrics have caught on fire, they offered } \\
\text { compensation and have now taken that away? } \\
\text { Even though I have it in emails. They offered } \\
\text { f500 which is shocking for the damage ... I have } \\
\text { evidence of everything including loss of } \\
\text { earnings }\end{array}$} & \multicolumn{2}{|c|}{$\begin{array}{l}\text { were told by TW we would have to get it } \\
\text { repaired and they would reimburse.... funnily } \\
\text { enough they found every reason under the sun } \\
\text { not to reimburse then agreed to pay half... we } \\
\text { are still waiting for the cheque over a year } \\
\text { later... }\end{array}$} \\
\hline $\begin{array}{l}\text { Owners } \\
\text { feeling } \\
\text { robbed }\end{array}$ & $\begin{array}{l}\text { WHEN PEOPLE BUY NEW!! AND PART } \\
\text { WITH SUCH LARGE SUMS OF CASH ITS } \\
\text { NOT UNREASONABLE TO EXPECT NEW } \\
\text { AND ANY ISSUES RAISED TO BE DEALT } \\
\text { WITH IN A TIMELY MANNOR BY } \\
\text { COMPETENT PEOPLE! ...I feel robbed }\end{array}$ & \multicolumn{2}{|c|}{$\begin{array}{l}\text { (They) changed the locks, } \\
\text { ran off with my keys and } \\
\text { refused to fix it ...I'm STILL } \\
\text { paying the monthly } \\
\text { mortgage of more than } \\
\text { f1,250 on an empty, } \\
\text { neglected house. }\end{array}$} & $\begin{array}{l}\text { I've never cried so much } \\
\text { over something that } \\
\text { should be a happy and } \\
\text { exciting time... There } \\
\text { refusing to cover all the } \\
\text { money we've lost so we } \\
\text { can pull out }\end{array}$ \\
\hline Lack of care & \multicolumn{2}{|c|}{$\begin{array}{l}\text { We had } 8 \text { attempts at our kitchen. Standard } \\
\text { problem everywhere and TW don't Care once } \\
\text { they have our cash }\end{array}$} & \multicolumn{2}{|c|}{$\begin{array}{l}\text { The biggest thing you will ever buy In your life } \\
\text { and we have no rights }\end{array}$} \\
\hline $\begin{array}{l}\text { Additional } \\
\text { fees / resale }\end{array}$ & \multicolumn{2}{|c|}{$\begin{array}{l}\text { My house is now unsaleable with doubling } \\
\text { ground rent and unregulated service charge. } \\
\text { We also have permission fees where we can't } \\
\text { even add a conservatory or paint the front door } \\
\text { without paying fees. }\end{array}$} & \multicolumn{2}{|c|}{$\begin{array}{l}\text { Just awaiting our court date. It cost us around } \\
\text { f7k of solicitors fees ... They won't refund our } \\
\text { legal fees so they left us no choice but to } \\
\text { pursue them through the small claims. They've } \\
\text { stated via their legal rep that we've no chance } \\
\text { of winning so to drop the claim. They've also } \\
\text { stated we'll be liable for their legal costs. We're } \\
\text { used to the excuses and big boy bully tactics so } \\
\text { off to court we go. }\end{array}$} \\
\hline $\begin{array}{l}\text { Waste of time } \\
\text { or money }\end{array}$ & $\begin{array}{l}\text { The NHBC are truly a waste of time and } \\
\text { money }\end{array}$ & \multicolumn{2}{|c|}{$\begin{array}{l}\text { I've bin chasing them to } \\
\text { do stuff for } 15 \text { months } \\
\text { wasted } 11 \text { days annual }\end{array}$} & $\begin{array}{l}\text { Word of advice folks } \\
\text { simply don't waste your } \\
\text { money buying } \\
\text { substandard crap }\end{array}$ \\
\hline
\end{tabular}


2 Money was a key concern, and the use of emojis here underlines the anger and frustration. The 'red 3 angry face' emoji after 'they have our cash'; the 'yellow disappointed face' emoji after we have no 4 rights, and the sarcastic use of the 'thumbs up' emoji after 'substandard' all add powerful emphasis. 5 Similarly, the anger sears through in capitalisation by the owner feeling robbed, having to part with 6 'SUCH LARGE SUMS OF CASH' (ff.cf. Craig, 2007) to buy a home. Again here the theme that 'we have 7 no rights' emerges, as does the anger at cost-cutting and 'cheap' poor quality materials at 'outrageous 8 prices' for the home. Perceived lack of responsibility to customers again emerges, companies 'refusing 9 to cover' costs and finding 'every reason under the sun' to not reimburse customers. Mention of the 10 NHBC being 'truly a waste of time and money' and customers being threatened with being 'liable for 11 their legal costs' also suggests change is required at a fundamental systemic level.

Table 7. Advice

\begin{tabular}{|l|l|l|l|l|}
\hline Themes & Comments \\
\hline $\begin{array}{l}\text { Don't buy } \\
\text { home }\end{array}$ & $\begin{array}{l}\text { Urging anyone } \\
\text { buying or thinking of } \\
\text { buying a ... home } \\
\text { don't!!! }\end{array}$ & $\begin{array}{l}\text { So if anyone on here } \\
\text { thinking of buying a } \\
\text { TW DONT DO IT. }\end{array}$ & $\begin{array}{l}\text { I would advise } \\
\text { anyone thinking of } \\
\text { buying a home from } \\
\text { them...DONT DO IT!! } \\
\text { AVOID THEM LIKE } \\
\text { THE PLAGUE!! }\end{array}$ & \begin{tabular}{l}
$\begin{array}{l}\text { As a Surveyor I } \\
\text { would advise anyone } \\
\text { who hasn't yet } \\
\text { bought a new home, } \\
\text { never ever buy 'off } \\
\text { plan'. Wait for the } \\
\text { property to be } \\
\text { completed first. If } \\
\text { this option isn't } \\
\text { available then just } \\
\text { walk away. }\end{array}$ \\
\hline $\begin{array}{l}\text { Homes } \\
\text { require } \\
\text { inspections }\end{array}$
\end{tabular} \\
$\begin{array}{l}\text { It's really important you all book an } \\
\text { Inspection as it is not just localised to the } \\
\text { development on watchdog. }\end{array}$ & $\begin{array}{l}\text { I SPEAK FROM EXPERIENCE....demand they } \\
\text { check your home fully to ensure it complies } \\
\text { to building regulations based on your home } \\
\text { design...and get the answer in writing by } \\
\text { way of a letter of compliance... }\end{array}$ \\
\hline
\end{tabular}

Many urged others not to buy a new home, and where they did, to have it inspected first. Clearly, customers felt they received a poor quality product (ef.cf. Parasuraman et al., 1985), particularly given the huge expense of buying a house (Craig, 2007). The powerful effect is again underlined by informal language and capitalisation, for example 'AVOID THEM LIKE THE PLAGUE!!' Such comments suggest the industry will be unable to change its 'cowboy' image (Proverbs et al., 2000) any time soon. Moreover, the advice to get their own inspection undertaken first suggests both that the show homes do not represent the final bought product (Georgiou et al., 1999) and that the NHBC, and the 
15 Table 8. NHBC

\begin{tabular}{|c|c|c|c|}
\hline Themes & Comments & & \\
\hline $\begin{array}{l}\text { NHBC } \\
\text { Failings / } \\
\text { Faults }\end{array}$ & $\begin{array}{l}\text { The NHBC Just left us homeless and } \\
\text { failed to book alternative } \\
\text { accommodation }\end{array}$ & $\begin{array}{l}\text { i have proof beyond doubt } \\
\text { that cost cutting by } \\
\text { deviating from original CAD } \\
\text { drawings will result in stair } \\
\text { failure and potential cost to } \\
\text { human life, and that this } \\
\text { issue isn't localised, it spans } \\
\text { across multiple regions... } \\
\text { both NHBC and the building } \\
\text { ombudsman are complicit } \\
\text { in turning a blind eye to } \\
\text { this issue }\end{array}$ & $\begin{array}{l}\text { NHBC confirmed it's a fault } \\
\text { however both Croudace } \\
\text { and NHBC are not willing to } \\
\text { carry out the repair and are } \\
\text { offering a cash settlement } \\
\text { of } f 1000 ! !\end{array}$ \\
\hline $\begin{array}{l}\text { Siding with } \\
\text { builder }\end{array}$ & $\begin{array}{l}\text { They wont bite the hand that feeds } \\
\text { them! They cant afford another } \\
\text { Persimmon! }\end{array}$ & $\begin{array}{l}\text { Unfortunately the builders } \\
\text { appear to be linked } \\
\text { favouring them with the } \\
\text { NHBC }\end{array}$ & $\begin{array}{l}\text { NHBC complaints allows } \\
\text { them } 28 \text { days to respond. } \\
\text { They will go past this and } \\
\text { send you a letter of } \\
\text { apology stating you can use } \\
\text { the ombudsman to take } \\
\text { things further. This is just a } \\
\text { way of passing buck against } \\
\text { the builder! }\end{array}$ \\
\hline $\begin{array}{l}\text { Waste of } \\
\text { time }\end{array}$ & $\begin{array}{l}\text { We had no joy at all! No response to ANY } \\
\text { emails or letters }\end{array}$ & $\begin{array}{l}\text { Nhbc is not worth the } \\
\text { paper its written on. } \\
\text { Absolutely useless. }\end{array}$ & $\begin{array}{l}\text { NHBC are not worth the } \\
\text { paper they are written on } \\
\text { they have not been able to } \\
\text { do anything to support us. }\end{array}$ \\
\hline $\begin{array}{l}\text { Deemed } \\
\text { Acceptable }\end{array}$ & $\begin{array}{l}\text { I have sent photos and quoted their own } \\
\text { tolerances that the wall and floor are not } \\
\text { within yet they seem disinterested and } \\
\text { say their tolerances are just guidelines? }\end{array}$ & \multicolumn{2}{|c|}{$\begin{array}{l}\text { The NHBC inspectors confirmed verbally to us that the } \\
\text { work done ... was atrocious and dangerous and had to be } \\
\text { fixed. They then sent a letter, four weeks later, confirming } \\
\text { they believed ... had done a job within the guidelines. The } \\
\text { drop they left outside our back door killed our dog! NHBC } \\
\text { should be binned }\end{array}$} \\
\hline
\end{tabular}




\begin{tabular}{|l|l|l|}
\hline Lies & Bunch of liars the lot of them. & $\begin{array}{l}\text { Finally had a reply from consumer... Trying to cover their } \\
\text { backsides now the inspector wrote in his reply "The areas } \\
\text { stated in the updated report were an indication - less has } \\
\text { been attended to in some areas, and greater areas have } \\
\text { been repointed elsewhere".. fed up with more lies. }\end{array}$ \\
\hline
\end{tabular}

1

2

3

4

5

6

7

8

9

10

11

12

13

14 Table 9. Ombudsman

\begin{tabular}{|l|l|l|}
\hline Themes & Comments \\
\hline $\begin{array}{l}\text { Positive } \\
\text { effect }\end{array}$ & $\begin{array}{l}\text { A New Homes Independent Ombudsman (if } \\
\text { available could have STOPPED so much } \\
\text { damage) }\end{array}$ & $\begin{array}{l}\text { We are fairly confident the Government has } \\
\text { taken note and will, in time, implement a } \\
\text { truly independent Ombudsman. }\end{array}$ \\
\hline $\begin{array}{l}\text { Negative } \\
\text { effect }\end{array}$ & $\begin{array}{l}\text { So our elected government has asked the } \\
\text { Home Builders Federation to come up with a } \\
\text { voluntary ombudsman? I can't see that... } \\
\text { championing new home buyers... and } \\
\text { certainly not holding plc housebuilder } \\
\text { members "to account" }\end{array}$ & $\begin{array}{l}\text { both NHBC and the building ombudsman are } \\
\text { complicit in turning a blind eye to this issue }\end{array}$ \\
\hline
\end{tabular}

The comments show customers had no faith in the NHBC. They were considered dishonest ('bunch of liars the lot of them'), a complete waste of time ('not worth the paper it's written on') and uncaring and ineffective ('left us homeless'). They were deemed closely aligned with the building companies (e.g. 'the builders appear to be linked'), and thus lacking any independence. Again, a disjunct between customer expectations and legal standards emerges. In relation to 'tolerances' and doing a 'job within the guidelines' there appears a huge gap between what these customers and NHBC considerations of what was appropriate. For customers, the NHBC understanding of appropriate was considered "atrocious and dangerous".

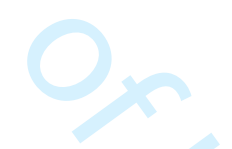

15

16

17

Regarding whether an independent ombudsman could resolve customer issues, customers were divided. One hoped that an ombudsman could have 'STOPPED' so much damage, and another was 'fairly confident' an ombudsman would be effective. Arguably, the key word in both these comments is 'independent'. Independence was key to this hope, and in comments of those pessimistic an ombudsman would be effective. One customer felt an ombudsman would be 'complicit' with the NHBC and another felt they would not have the ability (i.e. the power) to hold housebuilders 'to account'. Here again, the theme that systemic change is required was prominent, and the idea emerges it would need to be change that allowed a truly independent, and powerful, body to act on customers' behalf.

\section{Table 10. Page Closures}

\begin{tabular}{|l|l|}
\hline Themes & Comments \\
\hline
\end{tabular}




\begin{tabular}{|l|l|l|}
\hline $\begin{array}{l}\text { Page Taken } \\
\text { over }\end{array}$ & $\begin{array}{l}\text { Persimmon homes have just taken over the } \\
\text { persimmon homes unhappy buyers group. It's } \\
\text { deleting all threads of complaints and comments } \\
\text { and responding with 'call our customer care line' } \\
\text { it's also hidden the group so new people can't find }\end{array}$ & $\begin{array}{l}\text { Facebook received a complaint and } \\
\text { removed my post } \\
\text { didn't want us telling the mirror what } \\
\text { it's like to buy from TW!!!!! }\end{array}$ \\
& it & \\
\hline Regret & $\begin{array}{l}\text { It is with some regret that we have decided to close the Bovis Homes Victims Group } \\
\text { Facebook Group...We have done our best but we now need to get on with our lives. }\end{array}$ \\
\hline
\end{tabular}

1

2

3

4

5

6

7

8

9

10

11

12

13

14

15

16

17

18

19

20

21

22

23

24

25

26

27

28

29

30

31

32

33

34

35

36

37

38

The above comments show housebuilders are paying keen attention to social media; for example, by closing their own forums. One customer's comment and use of three 'angry red face' emojis shows their frustration at information being removed by Persimmon. Significantly, according to one source (Clarence-Smith, 2019) Persimmon paid Facebook to acquire the administrative rights to this page and was given these a week prior to the site's closure. Similarly, another customer's use of the 'curious thinking face' emoji alongside their comment to wonder who complained about their post suggests they think Taylor Wimpey similarly do not like public complaints. Bovis also closed their pages. Here these comments suggest housebuilders are unhappy this information is public.

\section{Discussion}

The above results paint a stark picture of the UK private housebuilding industry. Notably, and critically, they provide a picture that rarely emerges from current channels of feedback, as they are not 'managed' by the housebuilding companies. $\overline{-j}$ Tthey focus on technical items but the main focus is on the functional items which are arguably of greater importance to customers. Regarding quality, the results show customers feel the sector has abdicated responsibility for quality and standards. A huge lacuna exists between customer expectations regarding workmanship, quality, service, and the reality of the houses they buy and the NHBC's ability to help. This exists on all levels of experience, from scratches on windows, to soundproofing and quality of fittings, and far more serious issues such as houses collapsing and structural defects such as missing gable ends. Importantly, given their occurrence on social media forums, they attempt to convey messages in a way that emulates verbal and so they contain emojis, exclamation marks and capitals that communicate a more visceral and powerful message than written text alone can accomplish.

Most comments relate to functional issues regarding how houses look and feel, not to technical issues potentially covered by the NHBC. Understandably therefore, the comments relating to the NHBC are highly critical, given that concerns are not covered. A frustration and anger runs through these comments; customers feel 'robbed', and 'victims' of the companies. Given Persimmon sold almost half of their homes to first time buyers in 2019 through the help-to-buy scheme (Neate, 2019), these customers will be inexperienced in housebuying and perhaps less apprehensive, and possibly unaware of the industry's negative image (Proverbs et al., 2000). Clearly, as the comments show (particularly those relating to 'Advice') these customers, were they to buy again, would have very different criteria.

Yet, a cursory view of the Five-Star ratings of many UK housebuilders such as Persimmon and Taylor Wimpey would indicate everything is fine, with exemplary show-homes. However, such schemes are usurped by housebuilders (Boothman, et al.Eraig \& Somerville, 2018) for marketing purposes by seeking feedback at particular stages and strategically presenting the data as positively as possible. Similar strategic approaches are taken to websites; to their acquisition and to the management of negative feedback on social media sites where possible. 
Nevertheless, customers today can express-their views on social media transparently and openly. The above comments show the visceral and raw nature of these-customers' views, and a strong desire to inform others of their experiences to avoid them in the future. A clear message-is of the desire for a powerful and independent body to help. Some place hope in the Ombudsman, but others do not; minimal faith is placed in the NHBC, and there is a strong desire for change at a fundamental systemic level.

Despite numerous reports over the years championing current systemic political approaches

\section{Conclusion}

This paper has presented the results from social media comment posts from UK buyers of new-build homes. The overall picture is of anger, frustration, disbelief, and disempowerment in relation to the gulf between buyer expectations of their new home, and the reality of it. Some comments relate to technical issues (e.g. roof bracing) but most relate to functional issues regarding how the house looks and feels, issues not covered by the NHBC. Consequently, buyers cannot seek compensation nor make legal challenges, particularly as currently houses are not included in relevant UK government legal Acts. UK Housebuilders themselves strategically use current 'assurance' schemes such as the five-star rating system highly effectively in their marketing to encourage consumers to part with large sums of money for what is often their most expensive lifetime purchase. Notably, a house is an essential item, and, importantly, at the current time, the demand for new build homes far exceeds supply. UK private housebuilders are thus favourably placed to make healthy profits (ef.cf. Munday et al., 2014).

Nevertheless, these housebuilders are not immune to criticism although they seek to keep this to a minimum, as illustrated by their closing their own social media sites, and by the suggestion that they paid large sums of money to acquire and then close specific Facebook forums. The comments show a continuing negative picture of the UK private housebuilding sector (ff.cf.-Turin, 1969; Boothman et al.,Ramezany, 201가), but also, and significantly, do so without anonymity, and are powerful in their informal language, emojis and capitalisation. The messages are both visceral and unforgiving, both in their negative nature, and also in the absence of any positive comments of satisfaction or joy at the purchase made.

Against this drive for customer satisfaction and to understand quality expectations we have to balance a multi-billion pound industry manufacturing and producing very expensive consumer products, but with little research on the end-customer's expectations. Part of the problem with resolving the quality problem in housing is that unlike other industries, the private housebuilding sector has not tried to define what its customer's expectations and priorities are despite an increase in overall customer awareness and sophistication. The housebuilders of course could be asked to 
responsibility may better sit on the shoulders of numerous home buyers who have accepted products not up to expectation with lower than anticipated quality standards.

Arguably, new laws covering both functional and technical issues are required, and any new ombudsman needs significant powers and independence. Independence is key, and the perception shown above is that the bodies ostensibly empowered to help are not considered independent, thereby severely limiting the redress a homebuyer can seek. We suggest the UK government and any new ombudsman should draw on social media sources such as the above in an effort to fundamentally change the current system, perhaps introducing stricter regulations for quality as exist elsewhere (e.g. Singapore). Only with such root changes will the industry be able to rectify its long term negative image and start to instill a sense of pride and quality in its end product.

\section{References}

Arora, A., Bansal, S., Kandpal, C., Aswani, R., \& Dwivedi, Y. (2019). Measuring social media influencer indexinsights from facebook, Twitter and Instagram. Journal of Retailing and Consumer Services, 49, 86-101. DOI:10.1016/j.retconser.2019.03.012

Baldry, D. (1997). The image of construction and its influence upon client's, participants and consumers. In Proceedings of 13th Annual ARCOM Conference, Kings College Cambridge, September (Vol. 1, pp. 52-61).

Ball, M. (1988). Rebuilding construction: Economic change and the British construction industry. London: Routledge.

Barker, K. (2004), 'Review of Housing Supply: Securing our Future Housing Needs.' Her Majesty's Stationery Office: Norwich, UK

Barker, N (2020) 'Government confirms plans for New Homes Ombudsman.' Inside Housing Available at: athttps://www.insidehousing.co.uk/news/news/government-confirms-plans-for-new-homes-ombudsman65184 Last Accessed April 2020

Barrie, J. (2006), 'House of Horrors' Daily Record and Sunday Mail: Glasgow, UK.

BBC. (2019), 'Couples dream Persimmon home had 700 faults.' BBC Leeds and West Yorkshire. Available enline atonline at: https://www.bbc.co.uk/news/uk-england-leeds-47472832 Last Accessed July 2020

Branson, A. (2013), Top 150 Contractors and Housebuilders. Building: London, UK.

Bodapati S N and Naney D (2001) 'A Perspective on the Image of the Construction Industry.' 37th Annual ASC conference, 4-7 April 2001, Colorado, University of Denver, 213- 224.

Boothman, C, Craig, N and Sommerville, J (2018) "The UK housing developers' five star rating: fact or fiction?", Journal of Facilities Management, Vol. 16 Issue: 3, pp.269-283. DOI: 10.1108/JFM-10-2016-0039

Braun, V., \& Clarke, V. (2006). Using thematic analysis in psychology. Qualitative Research in Psychology, 3(2), 77-101. doi: 10.1191/1478088706qp063oa

Chu, S. C., \& Kim, Y. (2011). Determinants of consumer engagement in electronic word-of-mouth (eWOM) in social networking sites. International journal of Advertising, 30(1), 47-75. DOI:10.2501/IJA-30-1-047-075

Clark, R. (2005), 'Another Fine Mess.' The Daily Telegraph: London, UK

Clements, L., and Lewis, F (2019) 'The horror stories of people who have bought new Persimmon homes in Wales.' Wales Online Available at: https://www.walesonline.co.uk/news/wales-news/persimmonproblems-housing-new-wales-17317052 tast Accessed April 2020 Last Accessed July 2020

Craig, N. (2007). The prevailing trends of defects and snagging in new homes in the UK. Unpublished PhD. Thesis. Glasgow Caledonian University: Glasgow, UK

Curry, R (2019) Persimmon review finds fire safety issues and poor workmanship across housing stock. Available at: https://www.insidehousing.co.uk/news/news/persimmon-review-finds-fire-safety-issues-andpoor-workmanship-across-housing-stock-64552 Last Accessed April 2020

Curtis, M.D. (2011), 'New House Owners' Satisfaction Survey 2011.' Building Research Levy: Wellington. Egan, J. (1998) Rethinking Construction, the report of the construction task force, Her Majesty's Stationery Office. Norwich, UK

Emmerson, H. (1962). Survey of Problems Before the Construction Industries. London: HMSO.

Farmer, M. (2016), The Farmer Review of the UK Construction Labour Model - Modernise or Die. Cast Consultancy, Construction Leadership Council: London, UK 
Forsyth, $L$ and Sandhu, N (2019) Homeowners discover 700 faults in $£ 280,000$ new house after spending life savings. The Daily Mirror. Available at: https://www.mirror.co.uk/news/uk-news/homeowners-discover700-faults-280000-14089952 Last Accessed April 2020

Fusch, P. I., \& Ness, L. R. (2015). Are we there yet? Data saturation in qualitative research. The Qualitative Report, 20(9), $1408-1416$. ISSN $1052-0147$

Galati, A., Crescimanno, M., Tinervia, S., \& Fagnani, F. (2017). Social media as a strategic marketing tool in the Sicilian wine industry: Evidence from Facebook. Wine Economics and Policy, 6(1), 4047.DOI:10.1016/j.wep.2017.03.003

Gardiner, J., (2017), 'Here's the Snag.' Building Magazine, London, UK. Issue 15: 13/4/17.

Gardiner, J. (2019), Top 150 Contractors and Housebuilders. Building: London, UK.

Georgiou, J., Love, P.E.D. and Smith, J., (1999). A comparison of defects in houses in Victoria. Journal of Structural Survey. 17 (3) pp.160-169. ISSN 0263 - 080X

Greenslade, R (2009) Newspaper sales plunger over the decade. The Guardian, Available at: https://www.theguardian.com/media/2009/dec/14/national-newspapers-sales-decade Last Accessed April 2020

Haupt, T. and Harinarain, N. (2016). The image of the construction industry and its employment attractiveness. Acta Structilia, 23 (2), pp.79-108.DOI:10.18820/24150487/as23i2.

Hayek FA (1980) 'Individualism and Economic Order.' Chicago: University of Chicago Press.

HMSO, (1994) Sale and Supply of Goods Act 1994, Her Majesty's Stationery Office, Norwich, UK

HSE GOV., (2020) Health and Safety at Work etc Act 1974. Available at: https://www.hse.gov.uk/legislation/hswa.htm. Last accessed April 2020

ITV (2017) New Build Nightmares? Tonight. Details available at: https://www.itv.com/news/2017-06-08/newbuild-nightmares-tonight/ Last Accessed April 2020

Latham, M. (1994) Constructing the Team, Her Majesty's Stationery Office: London, UK

Local Government Association. (2017). Building regulations and building control. Local Government: Islington, London, UK

Lorentzen, C., (1996), A Challenging View on Building Control, Association of Building Engineers Conference, Bournemouth 1996.

Morgan, D. L. (1993). Qualitative content analysis: a guide to paths not taken. Qualitative health research, 3(1), 112-121. DOI:10.1177/104973239300300107

Munday, B. Falk, N. Hill, S. Clark, C. Tamahill, D. and Taylor, D. (2014), The ABC of Housing Growth and Infrastructure, the Housing Forum, London, UK.

Murray, M. (2005) 'House builders just don't care.' CIOB: Ascot, UK.

Neate, R. (2019). Outrage as help-to-buy boosts Persimmon profits to $f 1 \mathrm{bn}$. The Guardian. Available at: https://www.theguardian.com/business/2019/feb/26/persimmon-profits-help-to-buy-scheme Last Accessed April 2020

NHBC (2019). National New Homes Customer Satisfaction Survey (CSS). Available from: https://www.hbf.co.uk/policy/policy-and-wider-work-program/customer-satisfaction-survey/ Last Accessed April 2020

NHBC (2020) What is Buildmark? Available at http://www.nhbc.co.uk/Homeowners/WhatdoesBuildmarkcover/. Last Accessed April 2020

Parasuraman, A., Zeithaml, V., A and Berry, L.L., (1985). A conceptual model of service quality and its implications for future research. Journal of Marketing. 49 (4): pp 41-50[viewed 24th Feb 2020]. DOI:10.1177/002224298504900403

Pheng, S., \& Premnath. (2019). Construction Quality and the Economy. Springer. Singapore.

Proverbs, D G, Holt, G D and Cheok, H Y (2000) Construction industry problems: the views of UK construction directors. In: Akintoye, A (Ed.), 16th Annual ARCOM Conference, 6-8 September 2000, Glasgow Caledonian University. Association of Researchers in Construction Management, Vol. 1, 73-81

Ramezany, A., 2017. Critical Review of Factors that Lead to the Negative Image of the Construction Industry. tournal of Multidisciplinary Engineering Science and Technology. 4(3), pp.6796-6800. ISSN 2458-9403

Reichstein, T., Salter, A. and Gann, D., (2005), Last among equals: a comparison of innovation in construction, services and manufacturing in the UK. Construction Management \& Economics. 23(6), pp.631-644. DOI:10.1080/01446190500126940

Reid, E., \& Duffy, K. (2018). A netnographic sensibility: Developing the netnographic/social listening boundaries. Journal of Marketing Management, 34(3-4), 263-286.DOI:10.1080/0267257X.2018.1450282 
Rhodes, C., (2019). Construction Industry: Statistics and Policy. House of Commons Library: UK Parliament. Westminster: UK

Ruddick, G (2017) New homeowwners gagged over poor build and compensations claims https://www.theguardian.com/business/2017/feb/16/new-home-owners-gagged-over-poor-buildand-compensation-claims Last Accessed April 2020

Sargent, J (2020) Tackling the UK Construction Skills Shortage. Construction Europe. Available at: https://www.khl.com/construction-europe/tackling-the-uk-construction-skills-shortage/142170.article tast Accessed April 2020 Last Accessed July 2020

Sheldon, P. (2015). Social media: Principles and applications. Lexington Books.

Shewarth, W.A. (1931) Economic Control of Quality of Manufactured Product. New York: D van Nostrand Company Inc.

Sommerville, J. and McCosh, J. (2006) Defects in new homes: an analysis of data on 1696 new UK houses, Journal of Structural Survey, vol. 24, no. 1, pp. 6-21. ISSN: 0263-080X

Sommerville, J, Craig, N., and Callaghan, N (2012) House building service quality and buyer expectations In: Smith, S.D (Ed) Procs 28th Annual ARCOM Conference, 3-5 September 2012, Edinburgh, UK, Association of Researchers in Construction Management, 1025-1034.

Statista, (2020) Number of monthly active Facebook users worldwide as of $4^{\text {th }}$ Quarter 2019. Available at: https://www.statista.com/statistics/264810/number-of-monthly-active-facebook-users-worldwide/ Last Accessed April 2020

Furin, D., 1969. The construction industry: its economic significance and its role in development. UNIDO, London, UK.

Vale, L., and Fernandes, T. (2018). Social media and sports: driving fan engagement with football clubs on Facebook. Journal of strategic marketing, 26(1), 37-55. DOI:10.1080/0965254X.2017.135965

Vishwanath, A. (2015). Diffusion of deception in social media: Social contagion effects and its antecedents. Information Systems Frontiers, 17(6), 1353-1367. DOI:10.1007/s10796-014-9509-2

Voloshinov, V.N. (1973). Marxism and the philosophy of language (L. Matejka \& I.R. Titunik, Trans.). New York: Seminar Press. (Original work published 1929).

Weeks, B. E., Ardèvol-Abreu, A., \& Gil de Zúñiga, H. (2017). Online influence? Social media use, opinion leadership, and political persuasion. International Journal of Public Opinion Research, 29(2), 214-239. DOI: 10.1093/ijpor/edv050

Wilkinson, P. (2014), "The poor image of UK construction" Available at: http://blog.pwcom.co.uk/2014/12/22/the-poor-image-of-uk-construction/ Last accessed April 2020

Wu, H., Yue, K., Pei, Y., Li, B., Zhao, Y., \& Dong, F. (2016). Collaborative topic regression with social trust ensemble for recommendation in social media systems. Knowledge-Based Systems, 97, 111-122. DOI:10.1016/j.knosys.2016.01.011 


\section{Dear Richard,}

We've now revised our article in line with the comments from the reviewers and are much happier with it. We feel it is now much stronger as a result. We note that this process has added to the word count by about a thousand words but we have done our utmost to keep this below 9,000 for the article and note also that 299 words of this additional total is in the references in the end of text list. We also note that I terms of pages the total has only increased by 1 page to 17 now for the article. Do however let us know if we should reduce what we've added.

We also note that we have combed through carefully to attempt to ensure consistency in line with Harvard referencing for et al and for page citations. Sometimes we have accepted these in order not to reveal our name by the side. All other changes are shown through our having used the Tools Track Changes facility in Microsoft Word. We also detail below for each of the reviewers how we have responded to their comments. In addition we attach two documents (one for each reviewer) that we have saved as pdf in order to retain the highlights and shown changes and revisions where these details are outlined.

We were entirely in agreement with the reviewers and found their comments which we found both extremely insightful and also highly constructive. However, do please let us know if there is anything else we can do,

Best regards,

Nigel

Reviewer(s)' Comments to Author:

Referee: 1

Recommendation: Major Revision

Comments:

I think this article is both interesting and informative. As academic writing, I feel it needs to more clearly highlight the theoretical perspectives (lens) it is adopting. The methodology requires a stronger position to its content analysis and justification of coding and how such coding relates to the perspective being examined. I have inserted numerous comments within the document to further elaborate on these comments.

Our response: Many thanks for your constructive and incisive comments, particularly for putting these in the pdf so the location of their relation is clearly pinpointed. What we have done is to copy below each of your comments and to note its location in the paper, and to describe how we have responded afterwards. All changes we have made are clearly visible through our use of the Tools Track Changes facility in Microsoft Word. In 
addition we have responded to your comments in relation to the Additional Questions after each of these. Our responses are detailed after each one for these. Thank you again for your review and for what you have highlighted and noted. We deeply appreciate these and feel that the paper is far stronger and valuable as a result of responding to them. Do let us know however if there is anything else we can do.

Your comments from the pdf and how we have responded:

Comment 1. Lines 13 - 19 on page 1 in the pdf proof - 'citation required' in relation to the following sentence: "Most companies make healthy profits, and annual accounts of the top ten housebuilders from $2005 / 06$ to $2017 / 2018$ show profit margins ranging from $13.29 \%$ to $24 \%$ in 2005/06 and all but one housebuilder making yearly profits from $2013-2018 . "$

Our response: Thank you for noting this. We now add two citations form which figures can be attained as follows: Most companies make healthy profits, and annual accounts of the top ten housebuilders from $2005 / 06$ to $2017 / 2018$ show profit margins ranging from $13.29 \%$ to $24 \%$ in 2005/06 and all but one housebuilder making yearly profits from 2013 - 2018 (e.g. Branson, 2013, Gardiner, 2019).

Comment 2. Line 22 on page 1 in the pdf proof - 'Needs full title for International Readers' in relation to the following: "as illustrated by the recent 2016 APPG report."

Our response: Thank you for noting this - this is now added into the revised draft and copied here for reference with tools track changes highlighted: "as illustrated by the recent 2016 All-Party Parliamentary Group (APPG) report."

Comment 3. Line 24 on page 1 in the pdf proof - 'Again in full' in relation to the following: "MORI and HBF..."

Our response: Again thank you for noting this. We amend in the revised draft to include these in full for international readers as follows: "Market and Opinion Research International Ltd (MORI) and Home Builders Federation (HBF)"

Comment 4. Line 28 on page 1 in the pdf proof - 'Typo?' in relation to the word 'act' in the following: "the Sales of Goods Act of 1979 act (Sales of Goods Act, 1979 (HMSO, 1994))."

Our response: Thank you for spotting this. We have now removed the word 'act' here as follows:

"from the Sales of Goods Act of 1979 act(Sales of Goods Act, 1979 (HMSO, 1994))."

Comment 5. Lines 54 - 56 on page 1 in the pdf proof - 'Quote requires page reference' in relation to the following: "with Turin's (1969) noting that "construction has an image synonymous with high cost, low quality, chaotic working practices and a poor health and safety record" still resonant today (e.g. Ramezany, 2017)."

Our response: Thank you for noting this - in the current lockdown with Coronavirus we have unfortunately been unable to access the original book from the library. However, in our attempt to locate the source, and the source of the quote, we have encountered numerous other sources that highlight the same issues dating from 1931 to the 1960s, 1988, through to the present. We now put all of these to show the ongoing and perennial nature of such issues as follows: 
"Despite its significant benefits to the economy", the UK construction industry has continually battled with negative public perceptions, and has for decades faced issues of high cost, low quality and of poor health and safety (Emmerson, 1962; Ball, 1988; Boothman et al., 2018), with Turin's (1969) noting that "construction has an image synonymous with high cost, low quality, chaotic working practices and a poor health and safety record" still resonant today (e.g. Ramezany, 2017)."

Comment 6. Line 38 on page 2 in the pdf proof - 'What is this?' in relation to the 'npg' in the following - " "...holes in the ground" (Clements \& Lewis, 2019, npg). Notably..."

Our response: Thanks for asking this. We had assumed that the acronym 'npg' was universal in standing for 'no page given' and was used for websites. However, after revisiting the journal guidelines, seeing that the Harvard style is used, and then checking how this is approached in Harvard referencing from other sites, we see we are wrong. Rather than use 'npg' we see we need to specify in some other way - commonly by reference to which paragraph the citation is in. We therefore amend the one you noted in your comment (after we revisited the website) as follows:

"holes in the ground" (Clements \& Lewis, 2019, para. 1npg)."

We also revise all instances of ' $n p g$ ' in the draft to identify their location in the webpages - and we also amend the end of text list to reflect the more recent access dates.

Comment 7. After Line 35 on page 3 of the pdf proof - 'As this paper considers the impact / influence of social media upon building faults, perceptions etc I consider it appropriate to include in the literature review a discussion about social media. Although there may be little relating specifically to construction sector, there would no doubt be a large amount in consumer literature. This would extend to high involvement consumer behaviour such as housing.' - immediately at the end of the section after the following two final sentences - "The industry therefore would appear set to be able to continue regardless, and to build new homes often dangerously low in quality about which the public have little opportunity to spread widespread word of mouth about. That is, until the advent of social media."

Our response: Thank you for noting this. We have now undertaken further reading into social media how it is used in consumer literature and also drawn upon your own comments below and integrated these. We have studied in particular the elements you highlight such as 'herd mentality' issues of 'perception and reality' and the nature of social media communication by comparison with traditional communication and traditional media communication. Our revision of the paper has involved us physically moving the first section of the methodology that outlined how social media has been used to the end of the literature review and then expanded upon it. Further, we have added in greater detail this theoretical perspective on the nature of social media communication into the methodology. We detail how we have done this below for reference. In addition, we also comment on this in the discussion although haven't referred to it greatly as we feel that much of what we had written still stands, but - and we are extremely grateful to you for this and for highlighting that we should include more related to social media here - feel the article is much stronger with the theoretical basis outlined before it. However, do let us know what you think and if we should do more.

Changes as follows:

\footnotetext{
${ }^{1}$ As noted above, housing has recently been found to be worth $\mathrm{f} 41 \mathrm{billion}$ in revenue; as a whole the construction sector created $f 117$ billion in revenue in 2018 (Rhodes, 2019)
} 
A. End of the literature review and the methodology section:

The industry therefore would appear set to be able to continue regardless, and to build new homes often dangerously low in quality about which the public have little opportunity to spread widespread word of mouth about. That is, until the advent of social media.

Recent years have seen an explosion in social media platforms such as Facebook, Instagram and Twitter, with monthly active Facebook Users recently topping 2.5 billion worldwide (Statista, 2020). Social media channels of communication are the focus of much research in the area of marketing (e.g. Arora et al., 2019), with published literature ranging from areas such as attempting to engage fans of football clubs (Vale \& Fernandes, 2018) to strategic marketing of the Sicilian wine industry (Galati et al., 2017). Social media is considered to have a wider reach and greater impact than traditional media (Chu \& Kim, 2011), something which will increase over time, particularly with decreasing sales of traditional media such as newspapers (Greenslade, 2009). In the context of housebuilding, some have noted social media's potential to propel the discontent of new homeowners straight into the public domain, highlighting that private housebuilders must take quality seriously (Gardiner, 2017). Yet, to date, social media comments remain little researched in relation to the construction sector, despite the fact that housing is a key example of a product with high consumer involvement.

\section{Data: sources and approaches to collection and analysis.}

fecent vears have seen an explosion in social media platforms such as Faceook, Instagram and Iwitter, with monthly active Faceok Users recently topping 2.5 billion woldwide (Statista, 2020). Social media channels of communication are considered to have a wider reach and greater impact tha tradional media (Chu \& Kim, 2011), something which will increaseover time, paticulaty with decreasing sales of traditional media such as newspapers (Greenstade, 2009). In the context of housebuilding, some have noted socialmedia's potentialtopropel the discontent of new homeowners straight into the public domain, highlighting that private housebuilders must tak qualityseriously (Gardiner, 2017). Yet, to date, social mediamments comain little researched.

In this paper we present and discuss a combined content analysis (Morgan 1993) and thematic analysis (Braun \& Clarke, 2006) of comments ( $N=147)$ from Facebook forums that focused on the key themes related to quality in new build homes that were the concerns of owners. This combination allowed for the focus on key occurring issues in the content (Morgan, 1993) by focusing on their repeated mentions in responses by owners, yet gave the flexibility to identify emerging issues as well as those anticipated from the literature(Braun \& Clarke, 2006). Facebook Forums are- a form of online community that allow users to gain answers, advice and support, and connect with others, and comments posted are of an immediate and highly revealing nature (Reid \& Duffy, 2018). In essence, the comments are arguably similar to ones which would be shared in any face-to-face interaction, as research into social media shows that overall, an "overarching observation is that the two contexts are essentially similar" (Sheldon, 2015, p.15). Indeed, aspects such as the ability to influence others' opinions have been found to be broadly similar between traditional and social media (Weeks et al., 2017). Admittedly, much research into social media shows the presence of 'herd' mentality whereby individuals follow what others do (e.g. Vishwanath, 2015), thereby suggesting behaviour (and therefore what is said) online may differ greatly from behaviour and comments offline. However, such research tends to focus on how 'phishing' attackers can succeed by creating false popularity (Vishwanth, 2015), or how any herd mentality will operate by individuals' following friends recommendations on personal sites (Wu et al., 2016). In addition, there are subtle differences such as 
different expectancy norms online whereby more information is shared by an individual if they see others sharing frequently, and concern over privacy is greater even if private data is still shared (Sheldon, 2015). However, broadly speaking, offline and online communication is similar, and this is particularly so with non-personal sites such as Forums. Nevertheless, and as we argue here, the way in which the comments are communicated on such Forums is highly immediate and attempts to emulate and replicate conversational discussions. To do this, the visual impact of the comments is key, so rather than being presented as formally written and objective messages in text alone, they are interspersed with exclamation marks, emojis, and the use of capitals, in communication that more closely emulates the impact, intonation or stress of verbally delivered messages than written text alone (cf. Voloshinov, 1929).

Our data is drawn from 147 comments gathered from nine different forums set up by unsatisfied new home buyers and now used by thousands. This number was deemed sufficient to reach saturation (Fusch \& Ness, 2015) as any further comments repeated similar themes. The nine forums were selected as they had the highest number of members and therefore the most activity and prominence in any searches on Facebook (similarly as with a Google search). Anyone can join these forums and post freely, and the comments box displayed below each post allows others to question and discuss the original post. The providing a check on the information published, and increasing the reliability of the comments: Regarding hics, as faceok is public, comments are posted voluntarily and available for all tosee:

The comments were published in 2019 and 2020, and total just under 10,000 words. A 'comment' is a person giving their view on a situation, either an initial comment, or a response to another comment; it might focus on one issue (e.g. resealing windows) or on many (e.g. about the colour of mortar, but also NHBC). Comments ranged from 20 to 350 words or more. As noted immediately above, $t$ The effect of the comments is heightened by their informal linguistic nature, use of exclamation marks, photos, colloquial language, grammatical inaccuracies, and upper case capital letters and emojis for emphasis ${ }^{2}$. Such usage has a huge impact, and is particularly notable given the lack of anonymity. For example the comment "please share the hell out of this so others no [sic: know] to check everything" comes across with far greater impact in the original "PLEASE SHARE the hell out of this so others no [sic: know] to check EVERYTHING!!".

Analysis of the content was thematic, using a combined 'top-down' deductive and 'bottomup' inductive approach (Braun \& Clarke, 2006) to identify key themes. This was because it was assumed certain 'top-down' themes would be identifiable (e.g. 'safety' and 'workmanship') but considered unexpected themes might emerge 'bottom-up'. This was indeed the case, and provided a structure but allowed for a flexibility to accommodate unanticipated aspects. The pages are under constant scrutiny by other homeowners, providing a check on the information published, and increasing the reliability of the comments. A conscious strategy was adopted to select comments that had many other users posting responses of similar experiences. Whilst it is possible to interpret this as a herd mentality approach that illustrates a decoupling of perception and reality (cf. Vishwanath, 2015), we argue rather that this increases validity and reality, particularly as many comments reflected the experiences reported in the media, and were based not on personal preferences so much as events occurring in the homes. It was often the case that accompanying photographic images were posted for support. s. Regarding ethics, as Facebook is public, comments are posted voluntarily and available for all to see.

\footnotetext{
${ }^{2}$ We note that the emojis we use in this paper are not identical to those used in the social media posts in all cases (e.g. the shade of colour sometimes differs), but where they differ we have selected emojis as similar as possible, and have always selected those with an identical function.
} 


\section{B. Inclusion in the discussion}

This exists on all levels of experience, from scratches on windows, to soundproofing and quality of fittings, and far more serious issues such as houses collapsing and structural defects such as missing gable ends. Importantly, given their occurrence on social media forums, they attempt to convey messages in a way that emulates verbal and so they contain emojis, exclamation marks and capitals that communicate a more visceral and powerful message than written text alone can accomplish.

Comment 8. On Line 38 on page 3 of the pdf proof - 'I feel this methodological approach needs a stated theoretical perspective regarding how the data is analysed. The thematic approach stated by the author should also include a comment about themes searched and categorized for analysis' immediately after the title of the methodology section - "Data: sources and approaches to collection and analysis"

Our response: Thank you for noting this. As per the above we have now included a comment on how we have approached the analysis. This di, as you noted in your own comments, involve a content analysis, but combined this with a thematic analysis. We have now noted this at the outset of the Data Collection section at the very start as you suggest. This is shown immediately above but we also note it here for reference as follows:

In this paper we present and discuss a combined content analysis (Morgan 1993) and thematic analysis (Braun \& Clarke, 2006) of comments $(N=147)$ from Facebook forums that focused on the key themes related to quality in new build homes that were the concerns of owners. This combination allowed for the focus on key occurring issues in the content (Morgan, 1993) by focusing on their repeated mentions in responses by owners, yet gave the flexibility to identify emerging issues as well as those anticipated from the literature (Braun \& Clarke, 2006).

\section{Last Accessed}

Additional Questions:

1. Originality: Does the paper contain new and significant information adequate to justify publication? (i.e. is it a contribution to knowledge?): Yes. This paper examines an established and interesting area. The perspective of social media upon building success is a very interesting and addressing it here makes a contribution.

Our response: Thank you. We are very pleased to read your thoughts here.

2. Relationship to Literature: Does the paper demonstrate an adequate understanding of the relevant literature in the field and cite an appropriate range of literature sources? Is any significant work ignored to your knowledge?: I have included various notes in the .pdf file addressing this point. However, I feel the literature is lacking a discussion of social media, in the context of the built environment and also a theoretical direction. How is the reader to interpret what follows the lit review?

More focus within the review will aid in interpretation of the data and discussion 
Our response: We are extremely grateful to you for noting this and feel the paper is now much stronger and more grounded as a result of our responding to your comments and doing this (as outlined above). However, do please let us know your thoughts.

3. Methodology: Is the paper's argument built on an appropriate base of theory, concepts, or other ideas? Has the research or equivalent intellectual work on which the paper is based been well designed? Are the research methods employed appropriate?: The paper needs to better ground the methodological approach adopted, or at least more clearly stated. It is a content analysis of social media text and images. I feel some regard ought to be given to the "herd" mentality that can exist in such media and recognition of perception versus reality. Doing so would strengthen the article with regard to the analysis and discussion

Our response: Again we are extremely grateful for your comments and observations here and are much happier with the revised paper. Again though, do let us know your thoughts.

4. Results: Are results presented clearly and analysed appropriately? Do the conclusions adequately tie together the other elements of the paper?: Yes. I felt this was done quite well. However, the lack of a theoretical lens appears to cause this discussion to seem more of a "commentary" rather than an analysis of content data.

Our response: again thank you. We hope that our revisions now make what we have in the paper appear more an analysis of the data rather than a commentary.

5. Implications for research, practice and/or society: Does the paper identify clearly any implications for research, practice and/or society? Does the paper bridge the gap between theory and practice? How can the research be used in practice (economic and commercial impact), in teaching, to influence public policy, in research (contributing to the body of knowledge)? What is the impact upon society (influencing public attitudes, affecting quality of life)? Are these implications consistent with the findings and conclusions of the paper?: Industry implications are clear, theoretical implications not so clear (see comments above).

I believe this paper has strong industry relevance and sometimes that makes identifying a theoretical position difficult but doing so would increase the depth of the paper and findings.

Our response: Again we hope we have made this stronger in the revisions but do please let us know your thoughts.

6. Quality of Communication: Does the paper clearly express its case, measured against the technical language of the field and the expected knowledge of the journal's 
readership? Has attention been paid to the clarity of expression and readability, such as sentence structure, jargon use, acronyms, etc.: Written very well. Some initialism's and acronyms require naming in full for the benefit of international readers.

I felt this paper communicates its ideas and flows logically. Please note other comments and insert revisions in their appropriate sections.

Our response: Thank you for highlighting these. We have attempted to address both the ones you brought to our attention and also a number of issues in aligning how the references were presented to be more in line with the Harvard Style.

Referee: 2

Recommendation: Minor Revision

Comments:

Overall this was an interesting paper with simple information analysis that is useful for the housing industry.

It was unclear how 147 comments were selected and out of how many?

Since authors are providing policy recommendation, it may be worth using references from other countries which have strict building quality checks in place like Singapore.

Our response: Thank you we are very pleased to read this. Thank you also for highlighting how it is not clear how we selected the 147 comments and out of how many they were. In addition thank you for suggesting Singapore as an example of how quality checks can be introduced in the UK.

We have made changes in the revised document to integrate your observations and feel the paper is significantly stronger as a result. We have done this using Tools Track Changes but we also copy these here for reference and convenience:

In relation to the selection of the comments as follows:

1. "Our data is drawn from 147 comments gathered from nine different forums set up by unsatisfied new home buyers and now used by thousands. This number was deemed sufficient to reach saturation (Fusch \& Ness, 2015) as any further comments repeated similar themes. The nine forums were selected as they had the highest number of members and therefore the most activity and prominence in any searches on Facebook (similarly as with a Google search). Anyone can join these 
forums and post freely, and the comments box displayed below each post allows others to question and discuss the original post."

2. 'Analysis of the content was thematic, using a combined 'top-down' deductive and 'bottom-up' inductive approach (Braun \& Clarke, 2006) to identify key themes. This was because it was assumed certain 'top-down' themes would be identifiable (e.g. 'safety' and 'workmanship') but considered unexpected themes might emerge 'bottom-up'. This was indeed the case, and provided a structure but allowed for a flexibility to accommodate unanticipated aspects. The pages are under constant scrutiny by other homeowners, providing a check on the information published, and increasing the reliability of the comments. A conscious strategy was adopted to select comments that had many other users posting responses of similar experiences. Whilst it is possible to interpret this as a herd mentality approach that illustrates a decoupling of perception and reality (cf. Vishwanath, 2015), we argue rather that this increases validity and reality, particularly as many comments reflected the experiences reported in the media, and were based not on personal preferences so much as events occurring in the homes. It was often the case that accompanying photographic images were posted for support. s. Regarding ethics, as Facebook is public, comments are posted voluntarily and available for all to see."

In relation to references related to Singapore:

In the introduction:

"Further, many instruments ostensibly intended to assure quality, such as the Five-Star builders rating scheme, are used strategically by the housebuilding sector as marketing tools $\mathrm{s}_{L}$ and are heavily biased (Boothman, Craig \& Somerville, 2018). These fail to give the same certification and guarantee of quality that exists through regulatory structures such as those elsewhere in the world (e.g. Singapore (Pheng and Premnath, 2019)). Overall therefore, despite receiving media attention in programmes such as ITV Tonight's 'New Build Nightmares?' (ITV, 2017), individual customers have struggled to publically express views."

In the conclusion:

"We suggest the UK government and any new ombudsman should draw on social media sources such as the above in an effort to fundamentally change the current system, perhaps introducing stricter regulations for quality as exist elsewhere (e.g. Singapore). Only with such root changes will the industry be able to rectify its long term negative image and start to instill a sense of pride and quality in its end product."

Additional Questions:

1. Originality: Does the paper contain new and significant information adequate to justify publication? (i.e. is it a contribution to knowledge?): This is an original piece which is relevant for the housing industry.

Our response: Thank you we are very pleased to read this

2. Relationship to Literature: Does the paper demonstrate an adequate understanding of the relevant literature in the field and cite an appropriate range of literature sources? 
Is any significant work ignored to your knowledge?: Literature review was interesting to read.

Our response: Thank you we are very pleased to read this

3. Methodology: Is the paper's argument built on an appropriate base of theory, concepts, or other ideas? Has the research or equivalent intellectual work on which the paper is based been well designed? Are the research methods employed appropriate?: Overall this was an interesting paper with simple information analysis that is useful for the housing industry.

It was unclear how 147 comments were selected and out of how many?

Our response: Thank you for highlighting this we have now revised accordingly as outlined above. Do please let us know if there is anything else we can do further.

4. Results: Are results presented clearly and analysed appropriately? Do the conclusions adequately tie together the other elements of the paper?: Results are presented clearly and tied together with the research question.

Our response: Thank you we are very pleased to read this

5. Implications for research, practice and/or society: Does the paper identify clearly any implications for research, practice and/or society? Does the paper bridge the gap between theory and practice? How can the research be used in practice (economic and commercial impact), in teaching, to influence public policy, in research (contributing to the body of knowledge)? What is the impact upon society (influencing public attitudes, affecting quality of life)? Are these implications consistent with the findings and conclusions of the paper?: Overall this was an interesting paper with simple information analysis that is useful for the housing industry.

Our response: Thank you we are very pleased to read this

6. Quality of Communication: Does the paper clearly express its case, measured against the technical language of the field and the expected knowledge of the journal's readership? Has attention been paid to the clarity of expression and readability, such as sentence structure, jargon use, acronyms, etc.: The paper is well written.

Our response: Thank you we are very pleased to read this 


\section{Introduction}

3 In 2019 the UK construction sector was valued at over $£ 41 \mathrm{Bn}$; constituting $25 \%$ of the total UK 4 construction industry, with $21 \%$ of this amount being private housebuilding. This created 196,089 new 5 housing units across the UK in 2018 (Rhodes, 2019), although this figure remains below UK 6 Government targets. Most companies make healthy profits, and annual accounts of the top ten 7 housebuilders from 2005/06 to 2017/2018 show profit margins ranging from $13.29 \%$ to $24 \%$ in 8 2005/06 and all but one housebuilder making yearly profits from 2013 - 2018 (e.g. Branson, 2013, 9 Gardiner, 2019). Arguably, housing contractors should be keen to improve their reputations 10 (Wilkinson, 2014) and build quality. Indeed, private sector competitiveness has been the underpinning 11 12 ethos of UK government policy for the last 40 years (cf. Hayek, 1980) and claimed by many Government reports (e.g. Latham, 1994; Egan, 1998; Barker, 2004) to increase quality and value.

Yet, despite some Housebuilding Federation (HBF) surveys and results since 2000 showing improvements, much criticism of the sector exists (Baldry, 1997), and customer perceptions of end product quality are low, as illustrated by the recent 2016 All-Party Parliamentary Group (APPG) report. Buyers of private houses have been left in tears (Sommerville \& McCosh, 2006), experiencing severe stress from numerous faults (Craig, 2007) in what is commonly their largest lifetime purchase (Lorentzen, 1996). Market and Opinion Research International Ltd (MORI) and Home Builders Federation (HBF) annual surveys since 2000 show overall dissatisfaction with new-build homes and many defects reported. This situation is exacerbated by the absence of protective legislation, with newly built homes being exempt from the Sales of Goods Act of 1979 (Sales of Goods Act, 1979 (HMSO, 1994)). Further, many instruments ostensibly intended to assure quality, such as the Five-Star builders rating scheme, are used strategically by the housebuilding sector as marketing tools, are heavily biased (Boothman et al., 2018). These fail to give the same certification and guarantee of quality that exists through regulatory structures such as those elsewhere in the world (e.g. Singapore (Pheng and Premnath, 2019)). Overall therefore, despite receiving media attention in programmes such as ITV Tonight's 'New Build Nightmares?' (ITV, 2017), individual customers have struggled to publically express views.

However, the explosion in social media offers customers new outlets, and Facebook can reach wider and larger audiences than traditional media (Chu \& Kim, 2011). Facebook forums allow instant display of comments, and users can connect with others to share experiences, and gain advice (Reid \& Duffy, 2018). This paper first reviews key literature around quality and customer perceptions of the UK private housebuilding sector. It then presents and thematically analyses (Braun \& Clarke, 2006) 147 comment posts gathered from nine Facebook forums under themes of: safety; standards; quality; workmanship; customer service; finance and money; advice; NHBC; ombudsman and; page closures. Results corroborate the picture of poor quality in UK private housebuilding. Significantly, the novel use of social media forum comments provides a raw and often visceral picture of frustration, anger, and feelings of neglect. It is recommended such data be harnessed by official bodies and by the 'new home ombudsman' the UK Government aims to establish in 2020 (Barker, 2020) to help address the performance issues experienced. 
Despite its significance to the economy ${ }^{1}$, the UK construction industry has continually battled with negative public perceptions, and has for decades faced issues of high cost, low quality and of poor health and safety (Emmerson, 1962; Ball, 1988; Boothman et al., 2018). The Industry's low self-esteem and generally poor client relations (Farmer, 2016, p. 40) reinforce this. Negative public perceptions of the industry stem from building failures, quality issues, workforce accidents and fatalities, increases in cost and time, low professionalism, low productivity, and environmentally hazardous and disruptive practices (Bodapati \& Naney, 2001). The industry appears resistant to change, with some noting it lacks innovative thinking (Reichstein et al., 2005). The stereotype of the 'cowboy' builder, i.e. someone who is "incompetent, dishonest and a tax evader" (Proverbs et al., 2000, p. 74) remains widespread, perennially haunting the industry (Haupt \& Harinarain, 2016). Construction industry reports (notably Latham 1994; and Egan, 1998) do highlight the need to modernise to improve quality, efficiency, and thus the industry's reputation. However, such reports only commonly identify issues and fail to provide any overall strategy for change. As Proverbs et al. (2000) note, the aim of enhancing the reputation of the industry by improving quality and efficiency is common, but has not translated into practice.

Quality is key to improving the industry and, critically, play a fundamental role in customer expectations. Given the sizeable investment in a new-build home by a customer, it is understandable high levels of quality are expected (Parasuraman et al., 1985). Quality is measured by the gap between customers' expectation levels prior to receiving the product, and the actual expectation customers' have on receiving it (Sommerville et al., 2012). Since Aristotle, quality has been considered as "indicating the goodness of an object" (Shewarth, 1931, p.37). With buying a new build home, customer expectations are set by the contractor showcasing the prospective property via a 'show home', because ultimately the home builder is the client and it is they therefore that set the specification of the new home, not the home buyer (Craig, 2007, p. 2). Yet, 'show homes' are often furnished with premium high quality fittings and furnishings, and any failure to meet this high quality in the purchased final product can result in customer dissatisfaction (Georgiou et al., 1999). Contractors, perhaps understandably, present standards within show homes that are unlikely to be met, a situation encapsulated by Farmer $(2016$, p. 16) as being that "what is promised regardless of the challenge, is often not delivered".

Continuous monitoring by the UK government, the NHBC, and the HBF reveal starkly negative customer satisfaction. For example, a recent NHBC report found $99 \%$ of new build property owners reported snags or defects, and $34 \%$ found more problems than originally expected (NHBC, 2019). Of concern is both the sheer volume of these defects, and, importantly, their range and severity, "from leaky ceilings to holes in the ground" (Clements \& Lewis, 2019, para. 1). Notably, although previous research has suggested "the house price will generally reflect the quality an overall service received" (Craig, 2007, p. 47), it is increasingly apparent that even a premium price does not guarantee quality. Although anecdotal, this is evidenced by some new homeowners finding 700 defects in a new Persimmon $f 280,000$ house (Forsyth \& Sandhu, 2019). Similarly, by Clark's (2005) reports of faults with Charles Church homes, and by a customer's experience of finding fifty faults, some serious, in a $£ 310,000$ Barrett Home (Forsyth \& Sandhu, 2019, cf. Barrie, 2007).

In the mainstream media, such poor quality and attention to detail is frequently reported (e.g. Curtis, 2011). Murray (2005, p. 10) is quoted as saying "House builders just don't care" and more recent news, notes "the builder Persimmon lacks minimum house standards" (BBC, 2019, para. 1), with many new build homes lacking or incorrectly installing fire-stopping cavity barriers (BBC 2019). The extent and scale of defects is extreme, one owner, having her new Linden home deemed

\footnotetext{
${ }^{1}$ As noted above, housing has recently been found to be worth $f 41$ billion in revenue; as a whole the construction sector created $£ 117$ billion in revenue in 2018 (Rhodes, 2019)
} 
inhabitable by the NHBC, was still paying monthly bills and her mortgage (Deeks, 2019). A key issue is the many stages defects can be established and then impact later without any possibility of correction. For example, defects resulting by the site team will equate to increasing numbers and severity of defects at the handover stage (Wilkinson, 2014).

Regarding compensation and customer rights, although the Sales of Goods Act (1979 (HMSO, 1994)) does not protect house-buyers, certain guarantees are claimed to exist. The NHBC provides a 10 year warranty called Buildmark, and the Five-Star Builders scheme claims to give customers reliable housebuilder ratings before purchase (Boothman, et al., 2018). Under the Buildmark scheme, housing contractors provide warranties for the first two years, agreeing to rectify any defects not resulting from wear and tear or lack of maintenance, with the NHBC providing homeowners with an independent resolution service and guarantee (NHBC, 2020). Once this two-year period ends, the NHBC provides eight further years of protection for homeowners if contractors fail to meet NHBC requirements, but this is commonly from a technical viewpoint only. The homebuyer is exposed to many functional aspects (how the house looks and feels) although these functional items tend to be ignored (Craig, 2007, p. 46). Yet, the success of the Buildmark scheme is debatable. Some customers have complained, although relatively few published cases exist. Yet, this lack of published cases is often because the NHBC enforces homeowners to sign non-disclosure agreements, preventing them talking to the media and even neighbours about any issues (Ruddick, 2017). This both suggests the NHBC recognises the negative impact such perspectives could have, and also that dissatisfied homeowners have little ability to relate their experiences. Further, the Five Star Builders scheme intended to give customers a rating of their housebuilder before buying, is strategically implemented by the industry in marketing. By drawing on results gathered at particular stages in the house buying process, customers receive a biased, and overly favourable impression, of the housebuilder (Boothman, et al., 2018)

The ultimate impact of all the above on the industry is a negative one. This subsequently impacts on industry perceptions by those considering employment, who often conclude it is not a "desirable career path" (Sargent, 2020, introduction). There is a consequent significant skill shortage, and low productivity which contributes towards poor workmanship (Farmer, 2016, p. 16). This is despite government demand for homes targeting 300,000 new build homes a year by the mid-2020s (Sargent, 2020). Such initiatives as the Considerate Constructors Scheme (CCS), founded in 1997, have arguably had limited impact given continually emerging negative reports (e.g. Boothman et al., 2018). The industry therefore would appear impervious to change, continuing to build new homes often dangerously low in quality, which the public have little opportunity to comment about. That is, until the advent of social media.

Recent years have seen an explosion in social media platforms such as Facebook, Instagram and Twitter, with monthly active Facebook Users recently topping 2.5 billion worldwide (Statista, 2020). Social media channels of communication are the focus of much research in the area of marketing (e.g. Arora et al., 2019), with published literature ranging from areas such as attempting to engage fans of football clubs (Vale \& Fernandes, 2018) to strategic marketing of the Sicilian wine industry (Galati et al., 2017). Social media is considered to have a wider reach and greater impact than traditional media (Chu \& Kim, 2011), something which will increase over time, particularly with decreasing sales of traditional media such as newspapers (Greenslade, 2009). In the context of housebuilding, some have noted social media's potential to propel the discontent of new homeowners straight into the public domain, highlighting that private housebuilders must take quality seriously (Gardiner, 2017). Yet, to date, social media comments remain little researched in relation to the construction sector, despite the fact that housing is a key example of a product with high consumer involvement. 
2 Data: sources and approaches to collection and analysis.

In this paper we present and discuss a combined content analysis (Morgan 1993) and thematic

analysis (Braun \& Clarke, 2006) of comments ( $N=147$ ) from Facebook forums that focused on the key themes related to quality in new build homes that were the concerns of owners. This combination allowed for the focus on key occurring issues in the content (Morgan, 1993) by focusing on their repeated mentions in responses by owners, yet gave the flexibility to identify emerging issues as well as those anticipated from the literature (Braun \& Clarke, 2006). Facebook Forums are a form of online community that allow users to gain answers, advice and support, and connect with others, and comments posted are of an immediate and highly revealing nature (Reid \& Duffy, 2018). In essence, the comments are arguably similar to ones which would be shared in any face-to-face interaction, as research into social media shows that overall, an "overarching observation is that the two contexts are essentially similar" (Sheldon, 2015, p.15). Indeed, aspects such as the ability to influence others' opinions have been found to be broadly similar between traditional and social media (Weeks et al., 2017). Admittedly, much research into social media shows the presence of 'herd' mentality whereby individuals follow what others do (e.g. Vishwanath, 2015), thereby suggesting behaviour (and therefore what is said) online may differ greatly from behaviour and comments offline. However, such research tends to focus on how 'phishing' attackers can succeed by creating false popularity (Vishwanth, 2015), or how any herd mentality will operate by individuals' following friends recommendations on personal sites (Wu et al., 2016). In addition, there are subtle differences such as different expectancy norms online whereby more information is shared by an individual if they see others sharing frequently, and concern over privacy is greater even if private data is still shared (Sheldon, 2015). However, broadly speaking, offline and online communication is similar, and this is particularly so with non-personal sites such as Forums. Nevertheless, and as we argue here, the way in which the comments are communicated on such Forums is highly immediate and attempts to emulate and replicate conversational discussions. To do this, the visual impact of the comments is key, so rather than being presented as formally written and objective messages in text alone, they are interspersed with exclamation marks, emojis, and the use of capitals, in communication that more closely emulates the impact, intonation or stress of verbally delivered messages than written text alone (cf. Voloshinov, 1929).

Our data is drawn from 147 comments gathered from nine different forums set up by unsatisfied new home buyers and now used by thousands. This number was deemed sufficient to reach saturation (Fusch \& Ness, 2015) as any further comments repeated similar themes. The nine forums were selected as they had the highest number of members and therefore the most activity and prominence in any searches on Facebook (similarly as with a Google search). Anyone can join these forums and post freely, and the comments box displayed below each post allows others to question and discuss the original post.

The comments were published in 2019 and 2020, and total just under 10,000 words. A 'comment' is a person giving their view on a situation, either an initial comment, or a response to another comment; it might focus on one issue (e.g. resealing windows) or on many (e.g. about the colour of mortar, but also NHBC). Comments ranged from 20 to 350 words or more. As noted immediately above, the effect of the comments is heightened by their informal linguistic nature, use of exclamation marks, photos, colloquial language, grammatical inaccuracies, and upper case capital letters and emojis for emphasis ${ }^{2}$. Such usage has a huge impact, and is particularly notable given the

\footnotetext{
${ }^{2}$ We note that the emojis we use in this paper are not identical to those used in the social media posts in all cases (e.g. the shade of colour sometimes differs), but where they differ we have selected emojis as similar as possible, and have always selected those with an identical function.
} 
lack of anonymity. For example the comment "please share the hell out of this so others no [sic: know] to check everything" comes across with far greater impact in the original "PLEASE SHARE the hell out of this so others no [sic: know] to check EVERYTHING!!".

Analysis of the content was thematic, using a combined 'top-down' deductive and 'bottomup' inductive approach (Braun \& Clarke, 2006) to identify key themes. This was because it was assumed certain 'top-down' themes would be identifiable (e.g. 'safety' and 'workmanship') but considered unexpected themes might emerge 'bottom-up'. This was indeed the case, and provided a structure but allowed for a flexibility to accommodate unanticipated aspects. The pages are under constant scrutiny by other homeowners, providing a check on the information published, and increasing the reliability of the comments. A conscious strategy was adopted to select comments that had many other users posting responses of similar experiences. Whilst it is possible to interpret this as a herd mentality approach that illustrates a decoupling of perception and reality (cf. Vishwanath, 2015), we argue rather that this increases validity and reality, particularly as many comments reflected the experiences reported in the media, and were based not on personal preferences so much as events occurring in the homes. It was often the case that accompanying photographic images were posted for support. Regarding ethics, as Facebook is public, comments are posted voluntarily and available for all to see.

\section{Results and Analysis}

The results and qualitative analysis are categorised and presented below under ten themes of: safety; standards; quality; workmanship; customer service; finance and money; advice; NHBC; ombudsman and; page closures. Figure 1. details the number of comments in these themes:

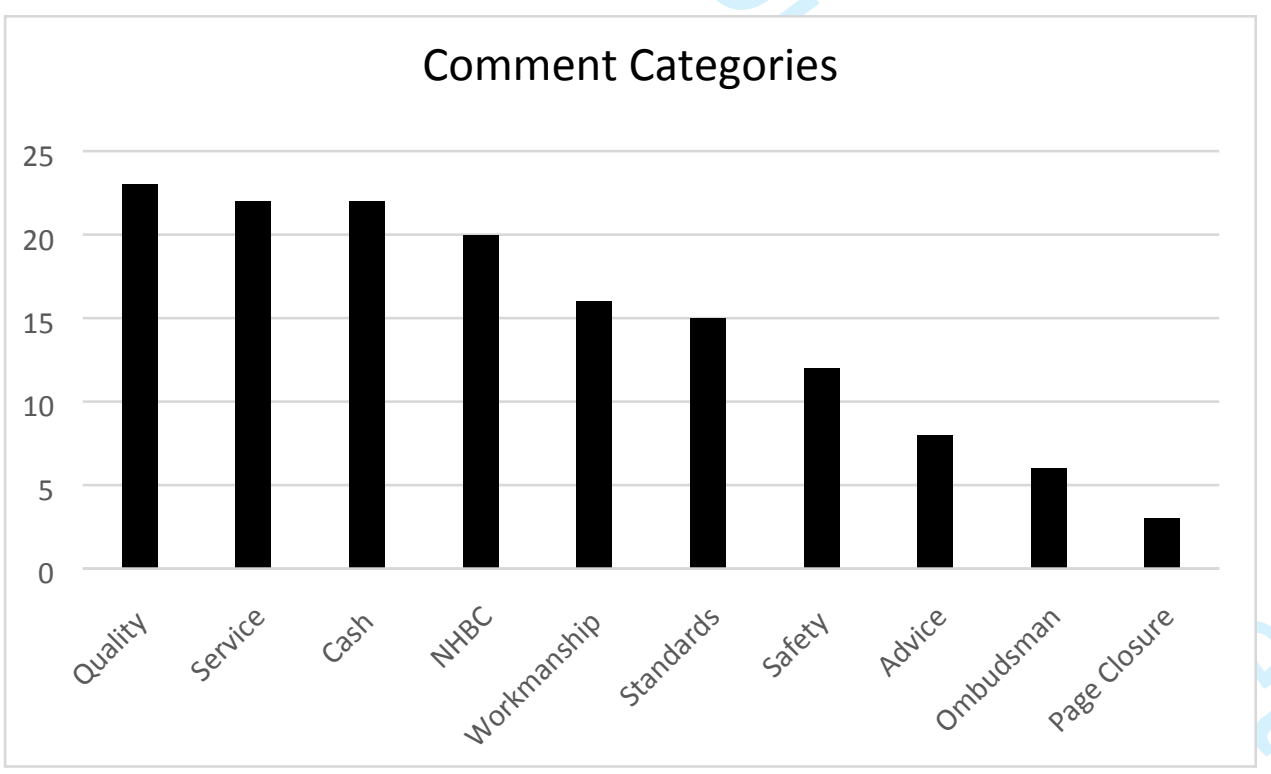

Figure 1: Numbers of comments obtained within each theme.

Below, we focus on each category in turn, first providing a selection of illustrative comments and subthemes in a table, then analysing these against the literature and other sources such as traditional media or legislation. Where comments related to more than one theme, the salient theme is focused on. As the comments are in the public domain, many housebuilders are named in the data selected below (Persimmon, Taylor Wimpey (TW), Croudace, and Linden). We note others were mentioned in the comments but are not in the selected data presented below (Bovis or Barratt). 
$1 \quad$ Table 1. Safety (issues highlighted)

\begin{tabular}{|l|l|l|l|}
\hline Themes & Comments \\
\hline $\begin{array}{l}\text { Poor } \\
\text { fixings }\end{array}$ & $\begin{array}{l}\text { Unsafe kitchens nearly killed my } \\
\text { pregnant wife... (Due to light weight } \\
\text { fixings) }\end{array}$ & $\begin{array}{l}\text { Typical Taylor Wimpey I } \\
\text { had tiles fall off the } \\
\text { room they don't seem } \\
\text { this serious until one hits } \\
\text { one of my kids }\end{array}$ & $\begin{array}{l}\text { The hand basin in my } \\
\text { downstairs toilet was } \\
\text { flexing on the wall... The } \\
\text { plasterboard was the only } \\
\text { thing holding the hand } \\
\text { basin up! No wonder it was } \\
\text { flexing. }\end{array}$ \\
\hline $\begin{array}{l}\text { Structural } \\
\text { security }\end{array}$ & $\begin{array}{l}\text { They opened a bedroom window } \\
\text { and it just fell out on to the patio! } \\
\text { Great house }\end{array}$ & $\begin{array}{l}\text { Sadly this is our home } \\
\text { that collapsed in the } \\
\text { middle of the night }\end{array}$ & $\begin{array}{l}\text { My Garage was marked } \\
\text { unsafe a couple of weeks } \\
\text { ago, amongst other } \\
\text { regulation breaches. }\end{array}$ \\
\hline $\begin{array}{l}\text { Safety of } \\
\text { the estate }\end{array}$ & $\begin{array}{l}\text { My } 4 \text { year old Son has tripped over } \\
\text { and split his head open on a } \\
\text { Persimmon... development site...I'm } \\
\text { fuming }\end{array}$ & $\begin{array}{l}\text { We had a break in last night...Be warned the locks } \\
\text { on patios are not anti snap... These burglars know } \\
\text { our locks are crap- change them now before your } \\
\text { the next victim. }\end{array}$ \\
\hline
\end{tabular}

2

3 Safety was key, and related to poor fixings, structural security or the safety of the estate. One property 4 owner's child tripped and severely hurt his head, as a road was incomplete. Here, despite it being the 5 contractor's duty to protect the health and safety of employees and the public (Health and Safety at 6 Work Act, 1974 (HSE Gov, 2020)), this comment suggests public safety is considered compromised. 7 Furthermore, regarding structural security, one customer's home collapsed entirely. This owner 8 posted photographs of the collapse on the forum, commenting further that the contractor is "acting 9 swiftly to correct all damage, which is positive, but sadly it takes something as horrendous \& 10 potentially fatal as this to get some decent customer service. Devastated." This incident was reported 11 on the BBC News (BBC 2019) and the same structural issues were highlighted on similarly designed 12 houses on the estate. Also, poor fixings in kitchens and bathrooms (cf. Barrie, 2007) were considered 13 instrumental in causing near accidents of a potentially serious nature, one customer reporting how he 14 felt his pregnant wife had nearly been killed, and another that falling tiles could at times hit children.

15 Table 2. Standards (technical items)

\begin{tabular}{|l|l|l|l|}
\hline Themes & Comments \\
\hline $\begin{array}{l}\text { Fire } \\
\text { Barriers }\end{array}$ & $\begin{array}{l}\text { No fire barriers, parts of houses } \\
\text { "falling off" why the hell are people } \\
\text { still buying them? }\end{array}$ & $\begin{array}{l}\text { Persimmon inspection } \\
\text { told me my cavity } \\
\text { barriers were ok } \\
\text { but...independent } \\
\text { inspector... identified I } \\
\text { have no barriers around } \\
\text { my electrical boxes. }\end{array}$ & $\begin{array}{l}\text { I've just had a call to say } \\
\text { my inspection from 11 } \\
\text { days ago (!!!!!) has } \\
\text { found that there are } \\
\text { 'some' missing fire } \\
\text { barriers. }\end{array}$ \\
\hline Plumbing & $\begin{array}{l}\text { The heating engineers...told me on their first visit } \\
\text { that the tank and how it had been installed was } \\
\text { well below standard. I rang and spoke to } \\
\text { persimmon customer services who were even } \\
\text { more shocking than the building work }\end{array}$ & $\begin{array}{l}\text { ffter having a leak from water tank } \\
\text { into downstairs toilet we discovered } \\
\text { blow off pipe from water tank was } \\
\text { never connected. They confirmed } \\
\text { it...didn't meet regulations...We also } \\
\text { discovered our water tank was never } \\
\text { commissioned }\end{array}$ \\
\hline $\begin{array}{l}\text { Structural } \\
\text { security }\end{array}$ & $\begin{array}{l}\text { Our TW home has been built (like many others on } \\
\text { our estate) without gable end straps }\end{array}$ & $\begin{array}{l}\text { Our block of flats are 4yrs old and } \\
\text { have been told we have subsidence. }\end{array}$ \\
\hline $\begin{array}{l}\text { Finishing } \\
\text { Quality }\end{array}$ & $\begin{array}{l}\text { (they) tell me this decorating and finish complies with their standards! Definitely not my } \\
\text { standards for a "luxury" house. }\end{array}$ \\
\hline
\end{tabular}


1 Customers were aware of issues relating to standards themselves (e.g. in relation to fire barriers) and 2 learned of issues from inspection reports (e.g. in relation to plumbing). Thus, in these forums there 3 was a synergy between customer knowledge, and knowledge from inspections, producing heightened 4 awareness of issues, and subsequent communication of these issues through social media. Although 5 building regulations and meeting minimum standards are legal requirements buildings must adhere 6 to (Local Government Association, 2017), it still remains possible, for whatever reasons, that for these 7 buyers certain building standards were not being met. These could be serious safety concerns 8 regarding fire barriers and structural security, or potentially damaging issues related to plumbing, or 9 mismatches in perceptions of 'standards' between builders and buyers (cf. Somerville et al. 2012).

11 Table 3. Quality issues in general

\begin{tabular}{|c|c|c|c|c|}
\hline Themes & \multicolumn{4}{|l|}{ Comments } \\
\hline Legislation & $\begin{array}{l}\text { Another few shots of Taylor Wimpey's } \\
\text { attempt of house building...if you think } \\
\text { these are rare cases and it will never } \\
\text { happen to you, well I was one of them } \\
\text { idiots who ignored the advice of current } \\
\text { TW homeowners!!!! You have been } \\
\text { warned } X\end{array}$ & \multicolumn{2}{|c|}{$\begin{array}{l}\text { I had to move out of my } \\
\text { Linden Home for the } \\
\text { SECOND time on 19/01/16 } \\
\text { and I've NEVER been able } \\
\text { to move back. (they) } \\
\text { changed the locks, ran off } \\
\text { with my keys and refused } \\
\text { to fix it }\end{array}$} & $\begin{array}{l}\text { The whole industry is so } \\
\text { badly run and new housing } \\
\text { legislation is so flawed you } \\
\text { all need to raise this with } \\
\text { your MP. }\end{array}$ \\
\hline Mould & $\begin{array}{l}\text { told the mold growing inside the kitchen } \\
\text { units and on the stairs... was because we } \\
\text { never put the heating on immediately to } \\
18^{\circ}\end{array}$ & \multicolumn{2}{|c|}{$\begin{array}{l}\text { mould above the front } \\
\text { door, underneath the } \\
\text { bathroom... }\end{array}$} & $\begin{array}{l}\text { issues round our windows! } \\
\text { Constantly growing } \\
\text { mould!! I'm wiping it away } \\
\text { every } 2 \text { days!! }\end{array}$ \\
\hline $\begin{array}{l}\text { Cracking / } \\
\text { Brickwork }\end{array}$ & $\begin{array}{l}\text { Has anybody had worse pointing than } \\
\text { this on their new build? I don't even } \\
\text { know what to say? I'm astounded that } \\
\text { it's passed any sort of inspection }\end{array}$ & \multicolumn{2}{|c|}{$\begin{array}{l}\text { this has to be the worst!!! } \\
\text { Major crack in the flooring } \\
\text { from one end of the house } \\
\text { to the other }\end{array}$} & $\begin{array}{l}\text { Within weeks the floors } \\
\text { were creaking along the } \\
\text { whole of the upstairs in } \\
\text { every room. Causing cracks } \\
\text { along the joins where } \\
\text { ceiling meets wall and } \\
\text { floor/ skirting boards... } \\
\text { They're all over you like a } \\
\text { rash when you're in the } \\
\text { process of buying, but the } \\
\text { second you move in that's } \\
\text { it. }\end{array}$ \\
\hline Garden & \multicolumn{2}{|c|}{$\begin{array}{l}\text { Apparently } 10 \text { inches of turf up the back of your } \\
\text { fence is acceptable because the fence is } \\
\text { "treated". }\end{array}$} & \multicolumn{2}{|c|}{$\begin{array}{l}\text { The garden floods constantly and floods the } \\
\text { garage ruining anything in there. The drain is six } \\
\text { inches above ground level, }\end{array}$} \\
\hline $\begin{array}{l}\text { Sound } \\
\text { proofing }\end{array}$ & \multicolumn{2}{|c|}{$\begin{array}{l}\text { I am kept awake by the neighbours boiler which is } \\
\text { on the party wall, switched on all night }\end{array}$} & \multicolumn{2}{|c|}{$\begin{array}{l}\text { We can hear neighbours voices clearly, light } \\
\text { switches and sockets being turned on and off, } \\
\text { blinds being opened }\end{array}$} \\
\hline
\end{tabular}

13 Quality was a key concern, and here, the 'bold red cross' emoji used by the customer regarding their overall experience of their house (legislation) and the 'person holding their hands up in despair' emoji at the crack in their flooring emphasise the feelings of anger and frustration. Also, the use of capitals (e.g. in relation to having to move out) and of exclamation marks (e.g in relation to the mould growing around the windows) further emphasise the degree of anger and frustration felt. Clearly, the comments suggest the aspiration for zero defects at handover (Egan, 1998) is not being met. Generally, comments focus on poor materials (windows), or poor workmanship (turf; pointing). Notably, a pattern emerges of either a mismatch between customer and housebuilder expectations of quality (Somerville et al., 2012), or of standards and minimum requirements not being met, and of the fault residing with the customer, not the housebuilder. One customer was "astounded that it's 
1 passed any sort of inspection" and another told that the mould was because they had not put "the

2 heating on immediately to $18^{\circ \prime}$. Poor soundproofing also suggests minimum standards not being met.

3 Here, an abdication of responsibility is clearly felt, the housebuilder described as "all over you like a

4 rash when you're buying, but the second you move in that's it."

5

6 Table 4. Workmanship

\begin{tabular}{|l|l|l|l|}
\hline Themes & Comments & $\begin{array}{l}\text { We bought a } \\
\text { Unsatisfied } \\
\text { truly shocking }\end{array}$ & $\begin{array}{l}\text { The whole industry } \\
\text { needs a massive shake } \\
\text { up }\end{array}$ \\
\hline Reworks & $\begin{array}{l}\text { Their excuse? The homes are all built by } \\
\text { hand so won't be perfect }\end{array}$ & $\begin{array}{l}\text { luxury" home, } \\
\text { definitely not. } \\
\text { Shoddy } \\
\text { workmanship and a } \\
\text { nightmare to get } \\
\text { snagging done. }\end{array}$ & $\begin{array}{l}\text { we've had 5 rooms re-plastered so far, how they } \\
\text { can claim to be a quality builder is beyond me. }\end{array}$ \\
\hline $\begin{array}{l}\text { Endless } \\
\text { Snags }\end{array}$ & $\begin{array}{l}\text { Our house has a huge number of } \\
\text { snags...they should have sold us a } \\
\text { completed house! }\end{array}$ & $\begin{array}{l}\text { We moved into a TW } \\
\text { property recently... } \\
\text { and pretty much } \\
\text { every window has } \\
\text { scratches inside the } \\
\text { glass. }\end{array}$ & $\begin{array}{l}\text { Utility room tap and } \\
\text { pipes... plumbed in } \\
\text { wrong... Downstairs loo } \\
\text { sink... hanging off the } \\
\text { wall and under sink } \\
\text { fittings looked like } \\
\text { they'd been flung on the } \\
\text { wall. Boiler was } \\
\text { connected wrong and } \\
\text { upstairs thermostat was } \\
\text { heating downstairs and } \\
\text { vice versa. }\end{array}$ \\
\hline
\end{tabular}

Comments related to workmanship suggest poor attention to detail and haste created endless snags, 9 a need for reworks (cf. Curry, 2019), and highly unsatisfied customers. Here again, the use of the three 10 'red angry face' emojis highlights anger at a perceived abdication of responsibility, that as "the homes 11 are all built by hand they won't be perfect." Further, there is a prevalence of minor faults, perhaps 12 due to haste, such as scratches in windows and incorrect plumbing. Here again, the mismatch again 13 between customer expectations and housebuilder products is clear, for example regarding what constituted a 'luxury' home. Notably, an emerging theme, which also arises below, is that the 'whole industry needs a massive shake-up.' In other words, that the causes of such issues are at a 16 fundamental and systemic level.

21 Table 5. Customer Service

\begin{tabular}{|l|l|l|l|}
\hline Themes & Comments \\
\hline $\begin{array}{l}\text { Service } \\
\text { attitude }\end{array}$ & $\begin{array}{l}\text { Kept our dignity despite awful, rude and } \\
\text { arrogant responses...site manager when }\end{array}$ & $\begin{array}{l}\text { The receptionist... is } \\
\text { extremely rude; we ask her }\end{array}$ & $\begin{array}{l}\text { We are having the same } \\
\text { encounters with customer }\end{array}$ \\
\hline
\end{tabular}




\begin{tabular}{|c|c|c|c|}
\hline 8 & $\begin{array}{l}\text { we moved in said "who signed this off?" } \\
\text { He didn't know what to say when we } \\
\text { said "you did!" }\end{array}$ & $\begin{array}{l}\text { what's her name and she } \\
\text { says you don't need to } \\
\text { know that, God Almighty!!! }\end{array}$ & $\begin{array}{l}\text { service. The area manager } \\
\text { is also extremely insulting. } \\
\text { We're still fighting } 9 \text { years } \\
\text { on!!! }\end{array}$ \\
\hline $\begin{array}{l}\text { Lack of } \\
\text { Customer } \\
\text { Service }\end{array}$ & $\begin{array}{l}\text { The customer service is appalling, how } \\
\text { they think they can speak to customers } \\
\text { and treat people this way is shocking. }\end{array}$ & $\begin{array}{l}\text { Customer service is } \\
\text { appalling... reported it to } \\
\text { Persimmon.... Phoned back } \\
\text { twice on Thursday as } \\
\text { nobody came. Eventually } \\
\text { spoke with the M.D. ... who } \\
\text { said a roofer would be here } \\
\text { first thing Friday. We have } \\
\text { tried contacting ... all day } \\
\text { as still nobody has been } \\
\text { but all calls gone to } \\
\text { answerphone }\end{array}$ & $\begin{array}{l}\text { We are not they're } \\
\text { customers, we are they're } \\
\text { victims! }\end{array}$ \\
\hline $\begin{array}{l}\text { Lack of } \\
\text { Response }\end{array}$ & $\begin{array}{l}\text { We've had nothing but problems with } \\
\text { the sales team, They never respond and } \\
\text { have barely guided us through any of } \\
\text { this process. }\end{array}$ & $\begin{array}{l}\text { I been fighting to get work } \\
\text { done for over a year....no } \\
\text { one cares...customer } \\
\text { service is a title only }\end{array}$ & $\begin{array}{l}\text { They don't care and the } \\
\text { site Forman and site } \\
\text { manager are a joke at the } \\
\text { persimmon development }\end{array}$ \\
\hline $\begin{array}{l}\text { What is } \\
\text { acceptable? }\end{array}$ & $\begin{array}{l}\text { Your fence is acceptable because the } \\
\text { fence is "treated". The words of the } \\
\text { assistant site manager. No mate, it's not } \\
\text { acceptable }\end{array}$ & $\begin{array}{l}\text { I am not accepting being } \\
\text { treated like a fool } \\
\text { anymore. }\end{array}$ & $\begin{array}{l}\text { After meeting with the big } \\
\text { cheeses from Persimmon.. } \\
\text { on Monday and hoping for } \\
\text { resolve... THE TERM ITS } \\
\text { WITHIN TOLERANCE was } \\
\text { used like verbal } \\
\text { Diarrhoea... }\end{array}$ \\
\hline
\end{tabular}

2 Reflecting the comments presented in above sections, customers were unhappy with the nature and 3 level of service. This could be service attitude of staff, or a lack of customer service or response, again underlining mismatches between customer expectations and housebuilder standards (cf. Somerville et al., 2012). The language is often highly informal and reveals intense anger, for example 'God Almighty!!!' with three exclamation marks. Also, the idea of customers being 'victims' and that 'they don't care' suggests a complete lack of any duty of care to customers (cf. Murray 2005). This is further illustrated by the housebuilder understanding of 'acceptable' relating to a fence being 'treated' clashing with the customer understanding, and the use of capitals for 'THE TERM ITS WITHIN TOLERANCE' showing frustration at this gap.

\begin{tabular}{|l|l}
\hline Themes & Comments
\end{tabular}




\begin{tabular}{|c|c|c|c|c|}
\hline Compensation & \multicolumn{2}{|c|}{$\begin{array}{l}\text { My electrics have caught on fire, they offered } \\
\text { compensation and have now taken that away? } \\
\text { Even though I have it in emails. They offered } \\
\text { f500 which is shocking for the damage ... I have } \\
\text { evidence of everything including loss of } \\
\text { earnings }\end{array}$} & \multicolumn{2}{|c|}{$\begin{array}{l}\text { were told by TW we would have to get it } \\
\text { repaired and they would reimburse.... funnily } \\
\text { enough they found every reason under the sun } \\
\text { not to reimburse then agreed to pay half... we } \\
\text { are still waiting for the cheque over a year } \\
\text { later... }\end{array}$} \\
\hline $\begin{array}{l}\text { Owners } \\
\text { feeling } \\
\text { robbed }\end{array}$ & $\begin{array}{l}\text { WHEN PEOPLE BUY NEW!! AND PART } \\
\text { WITH SUCH LARGE SUMS OF CASH ITS } \\
\text { NOT UNREASONABLE TO EXPECT NEW } \\
\text { AND ANY ISSUES RAISED TO BE DEALT } \\
\text { WITH IN A TIMELY MANNOR BY } \\
\text { COMPETENT PEOPLE! ...I feel robbed }\end{array}$ & \multicolumn{2}{|c|}{$\begin{array}{l}\text { (They) changed the locks, } \\
\text { ran off with my keys and } \\
\text { refused to fix it ...I'm STILL } \\
\text { paying the monthly } \\
\text { mortgage of more than } \\
£ 1,250 \text { on an empty, } \\
\text { neglected house. }\end{array}$} & $\begin{array}{l}\text { I've never cried so much } \\
\text { over something that } \\
\text { should be a happy and } \\
\text { exciting time... There } \\
\text { refusing to cover all the } \\
\text { money we've lost so we } \\
\text { can pull out }\end{array}$ \\
\hline Lack of care & \multicolumn{2}{|c|}{$\begin{array}{l}\text { We had } 8 \text { attempts at our kitchen. Standard } \\
\text { problem everywhere and TW don't Care once } \\
\text { they have our cash }\end{array}$} & \multicolumn{2}{|c|}{$\begin{array}{l}\text { The biggest thing you will ever buy In your life } \\
\text { and we have no rights }\end{array}$} \\
\hline $\begin{array}{l}\text { Additional } \\
\text { fees / resale }\end{array}$ & \multicolumn{2}{|c|}{$\begin{array}{l}\text { My house is now unsaleable with doubling } \\
\text { ground rent and unregulated service charge. } \\
\text { We also have permission fees where we can't } \\
\text { even add a conservatory or paint the front door } \\
\text { without paying fees. }\end{array}$} & \multicolumn{2}{|c|}{$\begin{array}{l}\text { Just awaiting our court date. It cost us around } \\
\text { f7k of solicitors fees ... They won't refund our } \\
\text { legal fees so they left us no choice but to } \\
\text { pursue them through the small claims. They've } \\
\text { stated via their legal rep that we've no chance } \\
\text { of winning so to drop the claim. They've also } \\
\text { stated we'll be liable for their legal costs. We're } \\
\text { used to the excuses and big boy bully tactics so } \\
\text { off to court we go. }\end{array}$} \\
\hline $\begin{array}{l}\text { Waste of time } \\
\text { or money }\end{array}$ & $\begin{array}{l}\text { The NHBC are truly a waste of time and } \\
\text { money }\end{array}$ & \multicolumn{2}{|c|}{$\begin{array}{l}\text { I've bin chasing them to } \\
\text { do stuff for } 15 \text { months } \\
\text { wasted } 11 \text { days annual }\end{array}$} & $\begin{array}{l}\text { Word of advice folks } \\
\text { simply don't waste your } \\
\text { money buying } \\
\text { substandard crap }\end{array}$ \\
\hline Cheap Quality & $\begin{array}{l}\text { They use cheap contractors and charge } \\
\text { outrageous prices for their homes }\end{array}$ & \multicolumn{3}{|c|}{ Everything is so cheap that it just breaks eventually } \\
\hline
\end{tabular}

1

2

3

4

5

6

7

8

9

10

11

12

13

14

15

16

17

Money was a key concern, and the use of emojis here underlines the anger and frustration. The 'red angry face' emoji after 'they have our cash'; the 'yellow disappointed face' emoji after we have no rights, and the sarcastic use of the 'thumbs up' emoji after 'substandard' all add powerful emphasis. Similarly, the anger sears through in capitalisation by the owner feeling robbed, having to part with 'SUCH LARGE SUMS OF CASH' (cf. Craig, 2007) to buy a home. Again here the theme that 'we have no rights' emerges, as does the anger at cost-cutting and 'cheap' poor quality materials at 'outrageous prices' for the home. Perceived lack of responsibility to customers again emerges, companies 'refusing to cover' costs and finding 'every reason under the sun' to not reimburse customers. Mention of the NHBC being 'truly a waste of time and money' and customers being threatened with being 'liable for their legal costs' also suggests change is required at a fundamental systemic level. 


\begin{tabular}{|l|l|l|l|l|}
\hline $\begin{array}{l}\text { Don't buy } \\
\text { a new } \\
\text { home }\end{array}$ & $\begin{array}{l}\text { Urging anyone } \\
\text { buying or thinking of } \\
\text { buying a ... home } \\
\text { don't!!! }\end{array}$ & $\begin{array}{l}\text { So if anyone on here } \\
\text { thinking of buying a } \\
\text { TW DONT DO IT. }\end{array}$ & $\begin{array}{l}\text { I would advise } \\
\text { anyone thinking of } \\
\text { buying a home from } \\
\text { them...DONT DO IT!! } \\
\text { AVOID THEM LIKE } \\
\text { THE PLAGUE!! }\end{array}$ & $\begin{array}{l}\text { As a Surveyor I } \\
\text { would advise anyone } \\
\text { who hasn't yet } \\
\text { bought a new home, } \\
\text { never ever buy 'off } \\
\text { plan'. Wait for the } \\
\text { property to be } \\
\text { completed first. If } \\
\text { this option isn't } \\
\text { available then just } \\
\text { walk away. }\end{array}$ \\
\hline $\begin{array}{l}\text { Homes } \\
\text { require } \\
\text { inspections }\end{array}$ & $\begin{array}{l}\text { It's really important you all book an } \\
\text { Inspection as it is not just localised to the } \\
\text { development on watchdog. }\end{array}$ & $\begin{array}{l}\text { I SPEAK FROM EXPERIENCE....demand they } \\
\text { check your home fully to ensure it complies } \\
\text { to building regulations based on your home } \\
\text { design...and get the answer in writing by } \\
\text { way of a letter of compliance... }\end{array}$ \\
\hline
\end{tabular}

1

2

3

4

5

6

7

8

9

10

11

12

13

14

15

16

17

18

19

20

21

22

23

24

Many urged others not to buy a new home, and where they did, to have it inspected first. Clearly, customers felt they received a poor quality product (cf. Parasuraman et al., 1985), particularly given the huge expense of buying a house (Craig, 2007). The powerful effect is again underlined by informal language and capitalisation, for example 'AVOID THEM LIKE THE PLAGUE!!' Such comments suggest the industry will be unable to change its 'cowboy' image (Proverbs et al., 2000) any time soon. Moreover, the advice to get their own inspection undertaken first suggests both that the show homes do not represent the final bought product (Georgiou et al., 1999) and that the NHBC, and the Buildmark scheme, are accorded little value. 


\begin{tabular}{|c|c|c|c|}
\hline $\begin{array}{l}\text { NHBC } \\
\text { Failings / } \\
\text { Faults }\end{array}$ & $\begin{array}{l}\text { The NHBC Just left us homeless and } \\
\text { failed to book alternative } \\
\text { accommodation }\end{array}$ & $\begin{array}{l}\text { i have proof beyond doubt } \\
\text { that cost cutting by } \\
\text { deviating from original CAD } \\
\text { drawings will result in stair } \\
\text { failure and potential cost to } \\
\text { human life, and that this } \\
\text { issue isn't localised, it spans } \\
\text { across multiple regions... } \\
\text { both NHBC and the building } \\
\text { ombudsman are complicit } \\
\text { in turning a blind eye to } \\
\text { this issue }\end{array}$ & $\begin{array}{l}\text { NHBC confirmed it's a fault } \\
\text { however both Croudace } \\
\text { and NHBC are not willing to } \\
\text { carry out the repair and are } \\
\text { offering a cash settlement } \\
\text { of } f 1000 ! !\end{array}$ \\
\hline $\begin{array}{l}\text { Siding with } \\
\text { builder }\end{array}$ & $\begin{array}{l}\text { They wont bite the hand that feeds } \\
\text { them! They cant afford another } \\
\text { Persimmon! }\end{array}$ & $\begin{array}{l}\text { Unfortunately the builders } \\
\text { appear to be linked } \\
\text { favouring them with the } \\
\text { NHBC }\end{array}$ & $\begin{array}{l}\text { NHBC complaints allows } \\
\text { them } 28 \text { days to respond. } \\
\text { They will go past this and } \\
\text { send you a letter of } \\
\text { apology stating you can use } \\
\text { the ombudsman to take } \\
\text { things further. This is just a } \\
\text { way of passing buck against } \\
\text { the builder! }\end{array}$ \\
\hline $\begin{array}{l}\text { Waste of } \\
\text { time }\end{array}$ & $\begin{array}{l}\text { We had no joy at all! No response to ANY } \\
\text { emails or letters }\end{array}$ & $\begin{array}{l}\text { Nhbc is not worth the } \\
\text { paper its written on. } \\
\text { Absolutely useless. }\end{array}$ & $\begin{array}{l}\text { NHBC are not worth the } \\
\text { paper they are written on } \\
\text { they have not been able to } \\
\text { do anything to support us. }\end{array}$ \\
\hline $\begin{array}{l}\text { Deemed } \\
\text { Acceptable }\end{array}$ & $\begin{array}{l}\text { I have sent photos and quoted their own } \\
\text { tolerances that the wall and floor are not } \\
\text { within yet they seem disinterested and } \\
\text { say their tolerances are just guidelines? }\end{array}$ & \multicolumn{2}{|c|}{$\begin{array}{l}\text { The NHBC inspectors confirmed verbally to us that the } \\
\text { work done ... was atrocious and dangerous and had to be } \\
\text { fixed. They then sent a letter, four weeks later, confirming } \\
\text { they believed ... had done a job within the guidelines. The } \\
\text { drop they left outside our back door killed our dog! NHBC } \\
\text { should be binned }\end{array}$} \\
\hline Lies & Bunch of liars the lot of them. & \multicolumn{2}{|c|}{$\begin{array}{l}\text { Finally had a reply from consumer... Trying to cover their } \\
\text { backsides now the inspector wrote in his reply "The areas } \\
\text { stated in the updated report were an indication - less has } \\
\text { been attended to in some areas, and greater areas have } \\
\text { been repointed elsewhere".. fed up with more lies. }\end{array}$} \\
\hline
\end{tabular}

The comments show customers had no faith in the NHBC. They were considered dishonest ('bunch of liars the lot of them'), a complete waste of time ('not worth the paper it's written on') and uncaring and ineffective ('left us homeless'). They were deemed closely aligned with the building companies 5 (e.g. 'the builders appear to be linked'), and thus lacking any independence. Again, a disjunct between 6 customer expectations and legal standards emerges. In relation to 'tolerances' and doing a 'job within 7 the guidelines' there appears a huge gap between what these customers and NHBC considerations of 8 what was appropriate. For customers, the NHBC understanding of appropriate was considered 9 "atrocious and dangerous". 


\begin{tabular}{|l|l|l|}
\hline $\begin{array}{l}\text { Positive } \\
\text { effect }\end{array}$ & $\begin{array}{l}\text { A New Homes Independent Ombudsman (if } \\
\text { available could have STOPPED so much } \\
\text { damage) }\end{array}$ & $\begin{array}{l}\text { We are fairly confident the Government has } \\
\text { taken note and will, in time, implement a } \\
\text { truly independent Ombudsman. }\end{array}$ \\
\hline $\begin{array}{l}\text { Negative } \\
\text { effect }\end{array}$ & $\begin{array}{l}\text { So our elected government has asked the } \\
\text { Home Builders Federation to come up with a } \\
\text { voluntary ombudsman? I can't see that... } \\
\text { championing new home buyers... and } \\
\text { certainly not holding plc housebuilder } \\
\text { members "to account" }\end{array}$ & $\begin{array}{l}\text { both NHBC and the building ombudsman are } \\
\text { complicit in turning a blind eye to this issue }\end{array}$ \\
\hline
\end{tabular}

1

2

3

4

5

6

7

8

9

10

11

12

13

14

15

16

17

18

19

20

21

22

23

24

25

26

27

28

Regarding whether an independent ombudsman could resolve customer issues, customers were divided. One hoped that an ombudsman could have 'STOPPED' so much damage, and another was 'fairly confident' an ombudsman would be effective. Arguably, the key word in both these comments is 'independent'. Independence was key to this hope, and in comments of those pessimistic an ombudsman would be effective. One customer felt an ombudsman would be 'complicit' with the NHBC and another felt they would not have the ability (i.e. the power) to hold housebuilders 'to account'. Here again, the theme that systemic change is required was prominent, and the idea emerges it would need to be change that allowed a truly independent, and powerful, body to act on customers' behalf.

\section{Table 10. Page Closures}

\begin{tabular}{|l|l|l|}
\hline Themes & Comments \\
\hline $\begin{array}{l}\text { Page Taken } \\
\text { over }\end{array}$ & $\begin{array}{l}\text { Persimmon homes have just taken over the } \\
\text { persimmon homes unhappy buyers group. It's } \\
\text { deleting all threads of complaints and comments } \\
\text { and responding with 'call our customer care line' } \\
\text { it's also hidden the group so new people can't find }\end{array}$ & $\begin{array}{l}\text { Facebook received a complaint and } \\
\text { removed my post } \\
\text { didn't want us telling the mirror what } \\
\text { it's like to buy from TW!!!!! }\end{array}$ \\
\hline it what the actual! \\
\hline
\end{tabular}

The above comments show housebuilders are paying keen attention to social media; for example, by closing their own forums. One customer's comment and use of three 'angry red face' emojis shows their frustration at information being removed by Persimmon. Significantly, according to one source (Clarence-Smith, 2019) Persimmon paid Facebook to acquire the administrative rights to this page and was given these a week prior to the site's closure. Similarly, another customer's use of the 'curious thinking face' emoji alongside their comment to wonder who complained about their post suggests they think Taylor Wimpey similarly do not like public complaints. Bovis also closed their pages. Here these comments suggest housebuilders are unhappy this information is public.

\section{Discussion}

The above results paint a stark picture of the UK private housebuilding industry. Notably, and critically, they provide a picture that rarely emerges from current channels of feedback, as they are not 'managed' by the housebuilding companies. They focus on technical items but the main focus is on the functional items which are arguably of greater importance to customers. Regarding quality, the results show customers feel the sector has abdicated responsibility for quality and standards. A huge 
lacuna exists between customer expectations regarding workmanship, quality, service, and the reality of the houses they buy and the NHBC's ability to help. This exists on all levels of experience, from scratches on windows, to soundproofing and quality of fittings, and far more serious issues such as houses collapsing and structural defects such as missing gable ends. Importantly, given their occurrence on social media forums, they attempt to convey messages in a way that emulates verbal and so they contain emojis, exclamation marks and capitals that communicate a more visceral and powerful message than written text alone can accomplish.

Most comments relate to functional issues regarding how houses look and feel, not to technical issues potentially covered by the NHBC. Understandably therefore, the comments relating to the NHBC are highly critical, given that concerns are not covered. A frustration and anger runs through these comments; customers feel 'robbed', and 'victims' of the companies. Given Persimmon sold almost half of their homes to first time buyers in 2019 through the help-to-buy scheme (Neate, 2019), these customers will be inexperienced in housebuying and perhaps less apprehensive, and possibly unaware of the industry's negative image (Proverbs et al., 2000). Clearly, as the comments show (particularly those relating to 'Advice') these customers, were they to buy again, would have very different criteria.

Yet, a cursory view of the Five-Star ratings of many UK housebuilders such as Persimmon and Taylor Wimpey would indicate everything is fine, with exemplary show-homes. However, such schemes are usurped by housebuilders (Boothman, et al., 2018) for marketing purposes by seeking feedback at particular stages and strategically presenting the data as positively as possible. Similar strategic approaches are taken to websites; to their acquisition and to the management of negative feedback on social media sites where possible.

Nevertheless, customers today can express views on social media transparently and openly. The above comments show the visceral and raw nature of these views, and a strong desire to inform others of their experiences to avoid them in the future. A clear message the desire for a powerful and independent body to help. Some place hope in the Ombudsman, but others do not; minimal faith is placed in the NHBC, and there is a strong desire for change at a fundamental systemic level.

Despite numerous reports over the years championing current systemic political approaches to the sector and suggesting changes and future approaches, nothing has changed. Perhaps because those bodies established to enforce any changes and ensure quality focus on technical rather than functional issues, and are too closely linked to a sector which has strategically usurped schemes of guarantees for marketing purposes. Without fundamental systemic change this will continue. What needs to be introduced are new laws to protect house buyers, and fully independent bodies to help them, with open transparent outlets for customers to express concerns. It is hoped the planned 'new homes ombudsman' will meet these criteria. As with standard day-to-day products, a house needs to be recognised as a product like any other, with strict and specific quality regulations related to both the house and the buying process.

\section{Conclusion}

This paper has presented the results from social media comment posts from UK buyers of new-build homes. The overall picture is of anger, frustration, disbelief, and disempowerment in relation to the gulf between buyer expectations of their new home, and the reality of it. Some comments relate to technical issues (e.g. roof bracing) but most relate to functional issues regarding how the house looks and feels, issues not covered by the NHBC. Consequently, buyers cannot seek compensation nor make legal challenges, particularly as currently houses are not included in relevant UK government legal 
Acts. UK Housebuilders themselves strategically use current 'assurance' schemes such as the five-star rating system highly effectively in their marketing to encourage consumers to part with large sums of money for what is often their most expensive lifetime purchase. Notably, a house is an essential item, and, importantly, at the current time, the demand for new build homes far exceeds supply. UK private housebuilders are thus favourably placed to make healthy profits (cf. Munday et al., 2014).

Nevertheless, these housebuilders are not immune to criticism although they seek to keep this to a minimum, as illustrated by their closing their own social media sites, and by the suggestion that they paid large sums of money to acquire and then close specific Facebook forums. The comments show a continuing negative picture of the UK private housebuilding sector (cf.; Boothman et al.,, 2018), but also, and significantly, do so without anonymity, and are powerful in their informal language, emojis and capitalisation. The messages are both visceral and unforgiving, both in their negative nature, and also in the absence of any positive comments of satisfaction or joy at the purchase made.

Against this drive for customer satisfaction and to understand quality expectations we have to balance a multi-billion pound industry manufacturing and producing very expensive consumer products, but with little research on the end-customer's expectations. Part of the problem with resolving the quality problem in housing is that unlike other industries, the private housebuilding sector has not tried to define what its customer's expectations and priorities are despite an increase in overall customer awareness and sophistication. The housebuilders of course could be asked to shoulder the blame for the lack of quality within housebuilding but, and we cannot ignore this, the responsibility may better sit on the shoulders of numerous home buyers who have accepted products not up to expectation with lower than anticipated quality standards.

Arguably, new laws covering both functional and technical issues are required, and any new ombudsman needs significant powers and independence. Independence is key, and the perception shown above is that the bodies ostensibly empowered to help are not considered independent, thereby severely limiting the redress a homebuyer can seek. We suggest the UK government and any new ombudsman should draw on social media sources such as the above in an effort to fundamentally change the current system, perhaps introducing stricter regulations for quality as exist elsewhere (e.g. Singapore). Only with such root changes will the industry be able to rectify its long term negative image and start to instill a sense of pride and quality in its end product.

\section{References}

Arora, A., Bansal, S., Kandpal, C., Aswani, R., \& Dwivedi, Y. (2019). Measuring social media influencer indexinsights from facebook, Twitter and Instagram. Journal of Retailing and Consumer Services, 49, 86-101. DOI:10.1016/j.retconser.2019.03.012

Baldry, D. (1997). The image of construction and its influence upon client's, participants and consumers. In Proceedings of 13th Annual ARCOM Conference, Kings College Cambridge, September (Vol. 1, pp. 52-61).

Ball, M. (1988). Rebuilding construction: Economic change and the British construction industry. London: Routledge.

Barker, K. (2004), 'Review of Housing Supply: Securing our Future Housing Needs.' Her Majesty's Stationery Office: Norwich, UK

Barker, N (2020) 'Government confirms plans for New Homes Ombudsman.' Inside Housing Available at: athttps://www.insidehousing.co.uk/news/news/government-confirms-plans-for-new-homes-ombudsman65184 Last Accessed April 2020

Barrie, J. (2006), 'House of Horrors' Daily Record and Sunday Mail: Glasgow, UK.

BBC. (2019), 'Couples dream Persimmon home had 700 faults.' BBC Leeds and West Yorkshire. Available online at :https://www.bbc.co.uk/news/uk-england-leeds-47472832 Last Accessed July 2020

Branson, A. (2013), Top 150 Contractors and Housebuilders. Building: London, UK.

Bodapati S N and Naney D (2001) 'A Perspective on the Image of the Construction Industry.' 37th Annual ASC conference, 4 -7 April 2001, Colorado, University of Denver, 213- 224. 
Boothman, C, Craig, N and Sommerville, J (2018) "The UK housing developers' five star rating: fact or fiction?", Journal of Facilities Management, Vol. 16 Issue: 3, pp.269-283. DOI: 10.1108/JFM-10-2016-0039

Braun, V., \& Clarke, V. (2006). Using thematic analysis in psychology. Qualitative Research in Psychology, 3(2), 77-101. doi: 10.1191/1478088706qp063oa

Chu, S. C., \& Kim, Y. (2011). Determinants of consumer engagement in electronic word-of-mouth (eWOM) in social networking sites. International journal of Advertising, 30(1), 47-75. DOI:10.2501/IJA-30-1-047-075

Clark, R. (2005), 'Another Fine Mess.' The Daily Telegraph: London, UK

Clements, L., and Lewis, F (2019) 'The horror stories of people who have bought new Persimmon homes in Wales.' Wales Online Available at: https://www.walesonline.co.uk/news/wales-news/persimmonproblems-housing-new-wales-17317052 Last Accessed July 2020

Craig, N. (2007). The prevailing trends of defects and snagging in new homes in the UK. Unpublished PhD. Thesis. Glasgow Caledonian University: Glasgow, UK

Curry, R (2019) Persimmon review finds fire safety issues and poor workmanship across housing stock. Available at: https://www.insidehousing.co.uk/news/news/persimmon-review-finds-fire-safety-issues-andpoor-workmanship-across-housing-stock-64552 Last Accessed April 2020

Curtis, M.D. (2011), 'New House Owners' Satisfaction Survey 2011.' Building Research Levy: Wellington.

Egan, J. (1998) Rethinking Construction, the report of the construction task force, Her Majesty's Stationery Office. Norwich, UK

Emmerson, H. (1962). Survey of Problems Before the Construction Industries. London: HMSO.

Farmer, M. (2016), The Farmer Review of the UK Construction Labour Model - Modernise or Die. Cast Consultancy, Construction Leadership Council: London, UK

Forsyth, L and Sandhu, N (2019) Homeowners discover 700 faults in $£ 280,000$ new house after spending life savings. The Daily Mirror. Available at: https://www.mirror.co.uk/news/uk-news/homeowners-discover700-faults-280000-14089952 Last Accessed April 2020

Fusch, P. I., \& Ness, L. R. (2015). Are we there yet? Data saturation in qualitative research. The Qualitative Report, 20(9), $1408-1416$. ISSN $1052-0147$

Galati, A., Crescimanno, M., Tinervia, S., \& Fagnani, F. (2017). Social media as a strategic marketing tool in the Sicilian wine industry: Evidence from Facebook. Wine Economics and Policy, 6(1), 4047.DOI:10.1016/j.wep.2017.03.003

Gardiner, J., (2017), 'Here's the Snag.' Building Magazine, London, UK. Issue 15: 13/4/17.

Gardiner, J. (2019), Top 150 Contractors and Housebuilders. Building: London, UK.

Georgiou, J., Love, P.E.D. and Smith, J., (1999). A comparison of defects in houses in Victoria. Journal of Structural Survey. 17 (3) pp.160-169. ISSN 0263 - 080X

Greenslade, R (2009) Newspaper sales plunger over the decade. The Guardian, Available at: https://www.theguardian.com/media/2009/dec/14/national-newspapers-sales-decade Last Accessed April 2020

Haupt, T. and Harinarain, N. (2016). The image of the construction industry and its employment attractiveness. Acta Structilia, 23 (2), pp.79-108.DOI:10.18820/24150487/as23i2.

Hayek FA (1980) 'Individualism and Economic Order.' Chicago: University of Chicago Press.

HMSO, (1994) Sale and Supply of Goods Act 1994, Her Majesty's Stationery Office, Norwich, UK

HSE GOV., (2020) Health and Safety at Work etc Act 1974. Available at: https://www.hse.gov.uk/legislation/hswa.htm. Last accessed April 2020

ITV (2017) New Build Nightmares? Tonight. Details available at: https://www.itv.com/news/2017-06-08/newbuild-nightmares-tonight/ Last Accessed April 2020

Latham, M. (1994) Constructing the Team, Her Majesty's Stationery Office: London, UK

Local Government Association. (2017). Building regulations and building control. Local Government: Islington, London, UK

Lorentzen, C., (1996), A Challenging View on Building Control, Association of Building Engineers Conference, Bournemouth 1996.

Morgan, D. L. (1993). Qualitative content analysis: a guide to paths not taken. Qualitative health research, 3(1), 112-121. DOI:10.1177/104973239300300107

Munday, B. Falk, N. Hill, S. Clark, C. Tamahill, D. and Taylor, D. (2014), The ABC of Housing Growth and Infrastructure, the Housing Forum, London, UK.

Murray, M. (2005) 'House builders just don't care.' CIOB: Ascot, UK.

Neate, R. (2019). Outrage as help-to-buy boosts Persimmon profits to $f 1 b n$. The Guardian. Available at: https://www.theguardian.com/business/2019/feb/26/persimmon-profits-help-to-buy-scheme Last Accessed April 2020 
NHBC (2019). National New Homes Customer Satisfaction Survey (CSS). Available from: https://www.hbf.co.uk/policy/policy-and-wider-work-program/customer-satisfaction-survey/ Last Accessed April 2020

NHBC (2020) What is Buildmark? Available at http://www.nhbc.co.uk/Homeowners/WhatdoesBuildmarkcover/. Last Accessed April 2020

Parasuraman, A., Zeithaml, V., A and Berry, L.L., (1985). A conceptual model of service quality and its implications for future research. Journal of Marketing. 49 (4): pp 41-50[viewed 24th Feb 2020]. DOI:10.1177/002224298504900403

Pheng, S., \& Premnath. (2019). Construction Quality and the Economy. Springer. Singapore.

Proverbs, D G, Holt, G D and Cheok, H Y (2000) Construction industry problems: the views of UK construction directors. In: Akintoye, A (Ed.), 16th Annual ARCOM Conference, 6-8 September 2000, Glasgow Caledonian University. Association of Researchers in Construction Management, Vol. 1, 73-81

Reichstein, T., Salter, A. and Gann, D., (2005), Last among equals: a comparison of innovation in construction, services and manufacturing in the UK. Construction Management \& Economics. 23(6), pp.631-644. DOI:10.1080/01446190500126940

Reid, E., \& Duffy, K. (2018). A netnographic sensibility: Developing the netnographic/social listening boundaries. Journal of Marketing Management, 34(3-4), 263-286.DOI:10.1080/0267257X.2018.1450282

Rhodes, C., (2019). Construction Industry: Statistics and Policy. House of Commons Library: UK Parliament. Westminster: UK

Ruddick, G (2017) New homeowwners gagged over poor build and compensations claims https://www.theguardian.com/business/2017/feb/16/new-home-owners-gagged-over-poor-buildand-compensation-claims Last Accessed April 2020

Sargent, J (2020) Tackling the UK Construction Skills Shortage. Construction Europe. Available at: https://www.khl.com/construction-europe/tackling-the-uk-construction-skills-shortage/142170.article Last Accessed July 2020

Sheldon, P. (2015). Social media: Principles and applications. Lexington Books.

Shewarth, W.A. (1931) Economic Control of Quality of Manufactured Product. New York: D van Nostrand Company Inc.

Sommerville, J. and McCosh, J. (2006) Defects in new homes: an analysis of data on 1696 new UK houses, Journal of Structural Survey, vol. 24, no. 1, pp. 6-21. ISSN: 0263-080X

Sommerville, J, Craig, N., and Callaghan, N (2012) House building service quality and buyer expectations In: Smith, S.D (Ed) Procs 28th Annual ARCOM Conference, 3-5 September 2012, Edinburgh, UK, Association of Researchers in Construction Management, 1025-1034.

Statista, (2020) Number of monthly active Facebook users worldwide as of $4^{\text {th }}$ Quarter 2019. Available at: https://www.statista.com/statistics/264810/number-of-monthly-active-facebook-users-worldwide/ Last Accessed April 2020

Vale, L., and Fernandes, T. (2018). Social media and sports: driving fan engagement with football clubs on Facebook. Journal of strategic marketing, 26(1), 37-55. DOI:10.1080/0965254X.2017.135965

Vishwanath, A. (2015). Diffusion of deception in social media: Social contagion effects and its antecedents. Information Systems Frontiers, 17(6), 1353-1367. DOI:10.1007/s10796-014-9509-2

Voloshinov, V.N. (1973). Marxism and the philosophy of language (L. Matejka \& I.R. Titunik, Trans.). New York: Seminar Press. (Original work published 1929).

Weeks, B. E., Ardèvol-Abreu, A., \& Gil de Zúñiga, H. (2017). Online influence? Social media use, opinion leadership, and political persuasion. International Journal of Public Opinion Research, 29(2), 214-239. DOI: 10.1093/ijpor/edv050

Wilkinson, P. (2014), "The poor image of UK construction" Available at:

http://blog.pwcom.co.uk/2014/12/22/the-poor-image-of-uk-construction/ Last accessed April 2020Wu, H., Yue, K., Pei, Y., Li, B., Zhao, Y., \& Dong, F. (2016). Collaborative topic regression with social trust ensemble for recommendation in social media systems. Knowledge-Based Systems, 97, 111-122.

DOI:10.1016/j.knosys.2016.01.011 